\title{
Rhodium(I) Complexes with Ligands Based on $N$-Heterocyclic Carbene and Hemilabile Pyridine Donors as Highly $(E)$ - Stereoselective Alkyne Hydrosilylation Catalysts
}

\author{
Judith P. Morales-Cerón, ${ }^{\dagger}$ Patricia Lara,${ }^{\star}$ Joaquín López-Serrano,${ }^{\ddagger}$ Laura L. Santos,${ }^{\star}$ Verónica \\ Salazar, ${ }^{* \dagger}$ Eleuterio Álvarez, ${ }^{\star}$ and Andrés Suárez*, \\ ${ }^{\dagger}$ Centro de Investigaciones Químicas. Universidad Autónoma del Estado de Hidalgo. \\ * Instituto de Investigaciones Químicas (IIQ), Departamento de Química Inorgánica and Centro de Innovación en Química \\ Avanzada (ORFEO-CINQA), CSIC and Universidad de Sevilla. \\ Supporting Information Placeholder
}

\begin{abstract}
Cationic rhodium(I) complexes containing picolyl-NHC (NHC $=N$-heterocyclic carbene) ligands that differ in the substitution at the 6-position of the pyridine donor serve as efficient $(E)$-selective alkyne hydrosilylation catalyst precursors. Particularly, by increasing the steric hindrance of the picolyl fragment, a catalyst precursor exhibiting high catalytic activities (TOF up to $500 \mathrm{~h}^{-1}$ at $\mathrm{S} / \mathrm{C}$ ratios of 1000$)$ and excellent $(E)$-selectivities $(E / \alpha$ ratio $\geq 95: 5)$ in the hydrosilylation of a series of aryl, alkyl and functionalized terminal alkynes with both carbo- and alcoxysilanes has been obtained. The picolyl-NHC ligands in the Rh complexes exhibit a dynamic behavior in solution due to the hemilabile coordination of the pyridine fragment. Preliminary mechanistic studies support the involvement of Rh silyl hydrido species, which are generated in low concentrations from Rh complexes and the silane, in the hydrosilylation of alkynes in agreement with the assumption of Chalk-Harrod-type mechanisms.
\end{abstract}

\section{INTRODUCTION}

Vinylsilanes are widely employed reactants in organic synthesis that can be conveniently accessed by the atomeconomical, metal-catalyzed hydrosilylation of alkynes. ${ }^{1,2}$ Although transition-metal catalysts for the addition of hydrosilanes to alkynes have been known for a long time, the search for active, and more importantly, selective catalysts still represents a challenge. For example, with respect to the selectivity issue, hydrosilylation of terminal alkynes produces up to three stereoisomers, namely $\beta-(Z)-, \quad \beta-(E)$ - and $\alpha$ isomers (Scheme 1). Among the various catalysts employed for alkyne hydrosilylation, those based on $\mathrm{Pt}$ give predominantly $\beta$ - $(E)$-alkenylsilanes, ${ }^{3}$ while the $\beta-(Z)$ - or $\alpha$ isomers are preferentially formed when $\mathrm{Ru}$ catalysts are employed. ${ }^{4,5}$ Other catalytic systems, like those based on Ir $^{6}$ and $\mathrm{Rh}^{3 \mathrm{a}, 7-16}$ provide $(E)$ - and $(Z)$-isomers depending on the precise nature of the catalysts, substrates and reaction conditions. In addition, metal catalyzed isomerization of $(Z)$ vinylsilanes to the most thermodynamically stable $(E)$-isomer has been observed. ${ }^{3 a, 6 a, 6 b, 66,8,10}$ Despite the significant advances made in the last years for the selective synthesis of the $\beta-(Z)$ and $\alpha$-isomers, few reliable alternatives to $\operatorname{Pt}(0)$ catalysts based on phosphine or $N$-heterocyclic carbene ligands have been envisaged for the synthesis of $(E)$-vinylsilanes (with the exception of some recently reported $\mathrm{Au}^{17}$ and $\mathrm{Co}^{18}$ catalysts), which use is usually hampered by both the high cost and air and moisture sensitivity of the catalysts. Therefore, since highly regio- and stereoselective predictable catalytic systems are limited, even for the more commonly accessible $(E)$ isomer, the development of new catalysts for this transformation is still desirable.
Scheme 1. Hydrosilylation of Terminal Alkynes

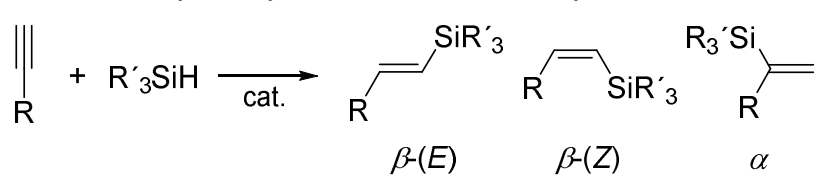

In the case of $\mathrm{Rh}(\mathrm{I})$ catalysts, neutral species normally show selectivity towards the formation of $\beta$ - $(Z)$-vinylsilanes, while cationic complexes provide predominantly $\beta$ - $(E)$ alkenylsilanes. $^{7-9}$ For example, in the hydrosilylation of alkylalkynes the cationic catalysts formed from $\left[\mathrm{Rh}(\mathrm{COD})_{2}\right] \mathrm{BF}_{4}+2 \mathrm{PPh}_{3}$ or $[\mathrm{Rh}(\mathrm{COD}) \mathrm{Cl}]_{2}+2 \mathrm{PPh}_{3}$ in polar solvents achieve high regio- and stereoselectivity for $\beta-(E)$ vinylsilane formation, ${ }^{7,10}$ whereas neutral rhodium complexes such as $\mathrm{RhCl}\left(\mathrm{PPh}_{3}\right)_{3}$ usually afford (Z)-alkenylsilanes with moderate to high selectivities. ${ }^{6 b, 11}$ Moreover, Rh-catalyzed hydrosilylation reactions usually depend on the addition order of the reagents, up to the point that some degree of regiocontrol was obtained and a stereodivergent synthesis of the anti-Markovnikov (Z)- and (E)-alkenylsilanes has been reported using neutral rhodium(I) iodide complexes. ${ }^{12}$ Also, a significant influence of other reaction parameters on selectivity such as concentration, ${ }^{11}$ solvent, ${ }^{10 a}$ and alkyne/silane ratio $^{8}$ have been observed. ${ }^{12,13}$ Another important factor affecting the reaction selectivity is the nature of the silane: ${ }^{11}$ electron-rich silanes tend to give $(Z)$-olefins with $\mathrm{Rh}$ catalysts, while $(E)$-products are obtained with electron-poor hydrosilanes such as $(\mathrm{RO})_{3} \mathrm{SiH}$. Hence, many $(E)$-selective rhodium catalysts are limited to the use of $\mathrm{R}_{3} \mathrm{SiH}$ silanes that lead to products of low synthetic value. ${ }^{2 \mathrm{~d}}$ Finally, an undesired drawback of Rh catalysts is also the occurrence 
of competitive processes such as the oligomerization ${ }^{19}$ and polymerization of arylalkynes, ${ }^{9,10 b, 12 b, 16 a, 20}$ and the formation of alkynylsilanes resulting from the dehydrogenative silylation of the alkynes. ${ }^{6 \mathrm{~b}-6 \mathrm{~d}, 14 \mathrm{~g}}$

In the last years there has been a significant interest in the development of $\mathrm{Rh}$ catalysts based on $\mathrm{N}$-heterocyclic carbene $(\mathrm{NHC})^{21}$ ligands for alkyne hydrosilylation. ${ }^{13-16}$ Particularly, focus has been placed, with limited success, on the use of NHC ligands containing hemilabile $\mathrm{N}$-donor groups (Figure 1). ${ }^{15,16}$ For example, initial work by Peris and coworkers has demonstrated the catalytic activity of a picolyl-carbene Rh complex in the addition of $\mathrm{HSiMe}_{2} \mathrm{Ph}$ to phenylacetylene. ${ }^{15} \mathrm{~A}$ temperature-dependent $(Z)$-selectivity was observed in this reaction, which was attributed to the isomerization of the initially formed $(Z)$-vinylsilane to the most stable $(E)$-isomer. Neutral and cationic Rh complexes with NHC containing dimethylamino groups have been reported by Jiménez, Oro and coworkers. ${ }^{16 a}$ Despite high $(Z)$-selectivity for the reaction of 1-hexyne with $\mathrm{HSiMe}_{2} \mathrm{Ph}$ was obtained, the catalysts show an alkyne-dependent selectivity and catalyze the $Z$ to $E$ isomerization of the resulting vinylsilanes upon prolonged reaction times. Also, in the reactions of phenylacetylene, extensive polymerization was observed. Similarly, the Cassani and Mazzoni group have reported neutral rhodium(I) BOCprotected amino NHC complexes that are active in the hydrosilylation of terminal alkynes with $\mathrm{HSiMe}_{2} \mathrm{Ph}^{16 \mathrm{~b}}$ Whereas no significant levels of selectivity were observed in the hydrosilylation reaction due to the $Z$ to $E$ isomerization process, the presence of an hemilabile donor group has been shown to provide a beneficial effect on the catalyst activity ("anchimeric assistance"). ${ }^{16 c}$ Finally, cationic Rh complexes based on tridentate NHC-pyrazole ligands have been shown to catalyze the hydrosilylation of phenylacetylene with triethylsilane, providing modest conversions and selectivities. $^{16 \mathrm{~d}}$
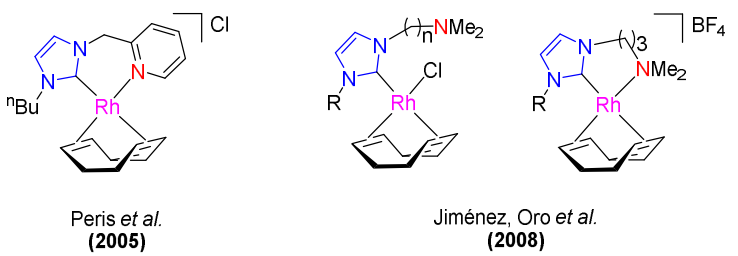

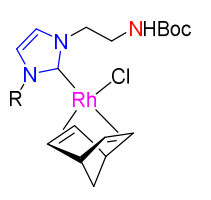

Cassani, Mazzoni et al. (2011)
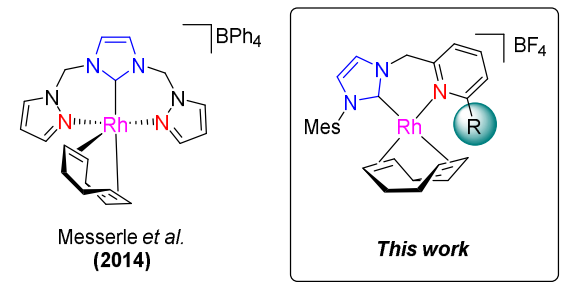

Figure 1. Rh(I) complexes with NHC ligands containing hemilabile $N$-donors for the hydrosilylation of terminal alkynes.

Herein, we report our studies on the hydrosilylation of acetylenes with a series of new cationic picolyl-NHC containing $\mathrm{Rh}$ complexes that differ in the steric hindrance at the 6-position of the hemilabile pyridine donor. These derivatives provide high catalytic activities and (E)selectivities in the addition of different silanes to a wide range of terminal alkynes. Furthermore, preliminary mechanistic investigation of the catalytic reactions is also described.

\section{RESULTS AND DISCUSSION}

Synthesis and Characterization of $\mathrm{Rh}$ Complexes. Imidazolium salts 1a-c were easily obtained by alkylation of 1-mesityl-1H-imidazole with the corresponding 2halomethylpyridines, as previously reported. ${ }^{22}$ NMR spectra of the salts are in agreement with the proposed structures and are consistent with previously reported data for analogous derivatives.

In a subsequent step, the corresponding silver complexes $(\mathrm{CN})(\mathrm{AgX})(\mathrm{X}=\mathrm{Cl}, \mathrm{Br})$ were prepared to be employed as NHC transfer reagents. ${ }^{23}$ Thus, reaction of imidazolium salts 1 with $\mathrm{Ag}_{2} \mathrm{O}$ in $\mathrm{CH}_{2} \mathrm{Cl}_{2}$ at room temperature resulted in the clean formation of silver complexes 2 (Scheme 2), ${ }^{22}$ as noted by the disappearance of the imidazolium proton signals at $c a .10 \mathrm{ppm}$ in the ${ }^{1} \mathrm{H}$ NMR spectra and appearance of broad signals at $c a$. 180 ppm in the ${ }^{13} \mathrm{C}\left\{{ }^{1} \mathrm{H}\right\}$ NMR experiments due to the $\mathrm{C}^{2}$ carbon of the $\mathrm{NHC}$ moieties.

Scheme 2. Synthesis of Silver (2) and Rhodium (3) Complexes

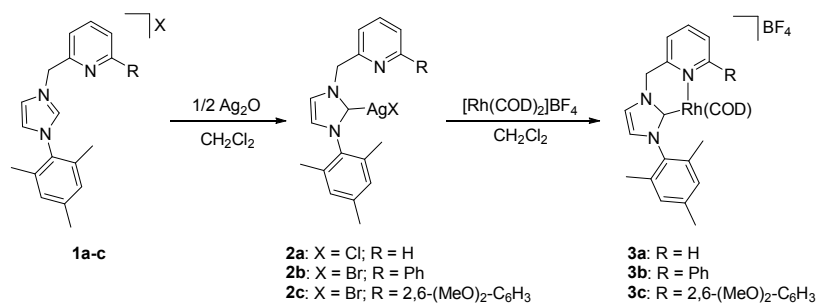

In turn, rhodium complexes 3a-c were conveniently prepared by carbene transfer from the appropriate silver complex 2 to $\left[\mathrm{Rh}(\mathrm{COD})_{2}\right] \mathrm{BF}_{4}$ in $\mathrm{CH}_{2} \mathrm{Cl}_{2}$ at room temperature, and were isolated with good yields as yellow-orange crystalline solids after recrystallization from $\mathrm{CH}_{2} \mathrm{Cl}_{2} / \mathrm{Et}_{2} \mathrm{O}$ solutions (Scheme 2). Complexes 3 were stable in the solid state under atmospheric conditions. Electrospray mass spectroscopy investigation of derivatives $\mathbf{3}$ produced peaks consistent with the expected molecular ion $\left[\mathrm{M}^{+}\right]^{+}$. Moreover, complexes $\mathbf{3}$ have been fully characterized by NMR techniques, and all of them were found to show very similar features. For example, in the ${ }^{1} \mathrm{H}$ NMR spectrum in $\mathrm{CD}_{2} \mathrm{Cl}_{2}$, the olefinic protons of the COD ligand produce four different signals between 2.3 and $4.8 \mathrm{ppm}$. In addition, the coordination of the pyridinyl moiety is evidenced from the observation of two doublets for the diastereotopic protons of the $\mathrm{CH}_{2}$ bridge appearing in the range between 5.7 and $6.5 \mathrm{ppm}\left({ }^{2} J_{\mathrm{HH}}=14-15\right.$ $\mathrm{Hz})$. The ${ }^{13} \mathrm{C}\left\{{ }^{1} \mathrm{H}\right\}$ NMR spectra show one doublet signal for the $\mathrm{C}^{2}(\mathrm{NHC})-\mathrm{Rh}$ carbon at $c a .178 \mathrm{ppm}\left(J_{\mathrm{CRh}}=52 \mathrm{~Hz}\right)$.

To gain further insight into the structure of coordinated picolyl-NHC ligands in complexes $\mathbf{3}$, crystals suitable for Xray diffraction analysis of $\mathbf{3 a}$ and $\mathbf{3 c}$ were obtained by slow diffusion of $\mathrm{Et}_{2} \mathrm{O}$ into saturated solutions of $\mathrm{CH}_{2} \mathrm{Cl}_{2}$ (Figure 2, Table 1). ${ }^{22 \mathrm{a}}$ In these complexes, the rhodium atom displays a square-planar geometry with the pyridine-imidazolinylidene ligand coordinated as a chelate. The bite angle of the picolylNHC ligand is $c a$. $84^{\circ}$. The $\mathrm{C}^{2}(\mathrm{NHC})-\mathrm{Rh}$ and $\mathrm{N}-\mathrm{Rh}$ bond lengths are similar to previously found distances, ${ }^{22 a, 24}$ although a significantly shorter $\mathrm{Rh}-\mathrm{N}$ distance for $\mathbf{3 a}$ than for $\mathbf{3 c}$ ( $c a$. $0.1 \AA$ ) has been found, probably as a consequence of the higher steric encumbrance due to the aryl substituent of the 
pyridine fragment. The average distances of the $\mathrm{C}_{\mathrm{COD}}-\mathrm{Rh}$ trans to the NHC are longer than those in the cis arrangement $[\Delta d(\mathrm{Rh}$-centroid $\mathrm{C}=\mathrm{C})=0.09 \AA \mathbf{( 3 a )}$ and $0.13 \AA(\mathbf{3 c})]$, as expected from the larger trans influence of the carbene donor. Also of interest, the chelate ring adopts a boat conformation that makes the two $\mathrm{CH}_{2}$ bridge protons non-equivalents, as previously inferred from the solution NMR study.

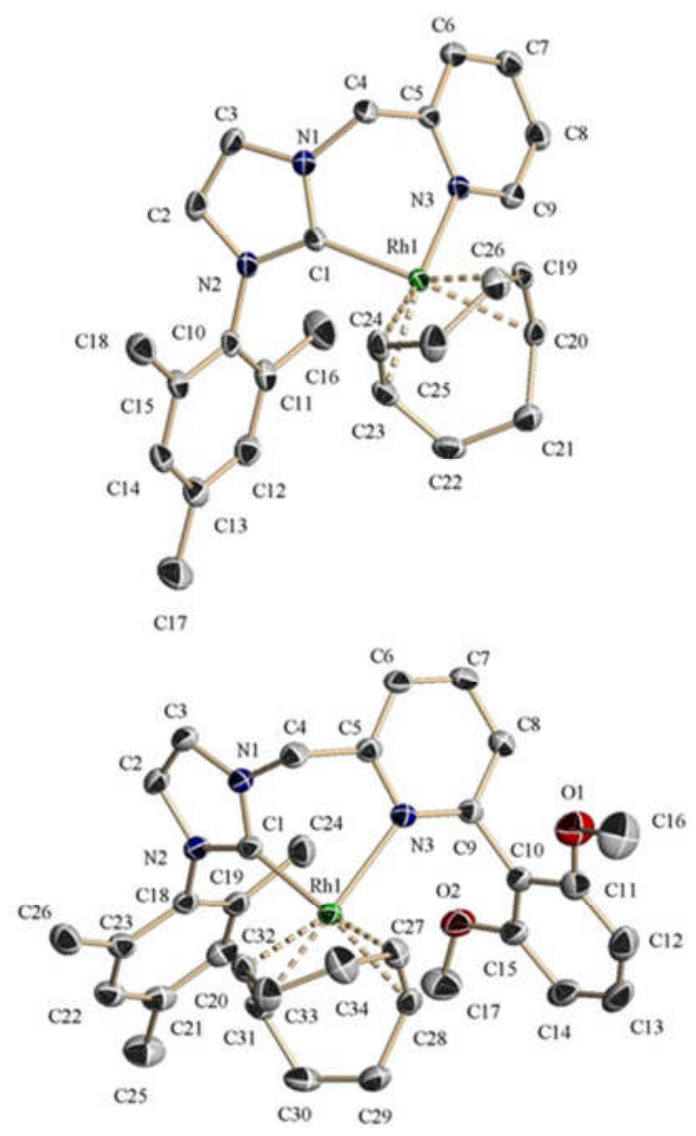

Figure 2. ORTEP drawings at $30 \%$ ellipsoid probability of the cationic fragments of complexes 3a (top) and $\mathbf{3 c}$ (bottom). Hydrogen atoms have been omitted for clarity.

Table 1. X-Ray Diffraction Bond Lengths (Å) and Angles ( ${ }^{\circ}$ ) for $3 a$ and $3 c$

\begin{tabular}{cccccc}
\hline & $\mathrm{Rh}-\mathrm{C}_{N H C}$ & $\mathrm{Rh}-\mathrm{N}_{P y}$ & $\begin{array}{c}\mathrm{Rh}-\mathrm{C}= \\
\text { trans NHC }\end{array}$ & $\begin{array}{c}\mathrm{Rh}-\mathrm{C}= \\
\text { cis NHC }\end{array}$ & $\begin{array}{c}\mathrm{C}_{N H C}-\mathrm{Rh}-\mathrm{N} \\
P y\end{array}$ \\
\hline 3a & $2.013(3)$ & $2.115(2)$ & $2.187(3)$ & $2.139(3)$ & $84.07(10)$ \\
& & & $2.252(3)$ & $2.131(3)$ & \\
3c & $2.039(3)$ & $2.213(2)$ & $2.208(3)$ & $2.107(3)$ & $84.62(9)$ \\
& & & $2.238(3)$ & $2.100(3)$ & \\
\hline
\end{tabular}

Dynamic Behavior of Complexes 3 in Solution. Dynamic hemilabile coordination of heteroditopic ligands have been shown to enhance the catalytic performance by creating transi- ent vacant coordination sites and stabilizing unsaturated catalytic intermediates. ${ }^{25}$ Since the hemilabile character of the picolyl-NHC ligands can be anticipated due to the presence of a strong $\sigma$-donor NHC fragment and a weaker bound $\mathrm{sp}^{2}-\mathrm{N}$ function, the solution dynamics of complexes 3a-c in $\mathrm{CD}_{2} \mathrm{Cl}_{2}$ and $\mathrm{CD}_{3} \mathrm{CN}$ have been studied by ${ }^{1} \mathrm{H},{ }^{1} \mathrm{H}$-EXSY and VT- ${ }^{1} \mathrm{H}$ NMR spectroscopies.

In $\mathrm{CD}_{2} \mathrm{Cl}_{2}$, the ${ }^{1} \mathrm{H}$ NMR spectra registered between -10 and $55{ }^{\circ} \mathrm{C}$ of complex 3a show the existence of a fluxional behavior. At $-10{ }^{\circ} \mathrm{C}$ the presence of two doublets signals at 6.01 and $5.65 \mathrm{ppm}\left({ }^{2} J_{\mathrm{HH}}=14.7 \mathrm{~Hz}\right)$ corresponding to the protons of the methylene backbone is observed. These signals significantly broaden upon heating, and finally coalesce at 55 ${ }^{\circ} \mathrm{C}$. Line-shape analysis of the ${ }^{1} \mathrm{H}$ NMR spectra gives activation parameters values of $\Delta H^{\star}=11.4 \mathrm{Kcal} / \mathrm{mol}$ and $\Delta S^{\star}$ $=-13$ eu (Table 2). In the ${ }^{1} \mathrm{H},{ }^{1} \mathrm{H}$-EXSY spectrum of $\mathbf{3 a}$, intense cross-peaks due to chemical exchange are observed between the signals of the two olefinic protons of the $\mathrm{CH}=\mathrm{CH}$ fragment trans to the $\mathrm{NHC}$ and between the alkene protons trans to the pyridine. However, no exchange signals involving the $\mathrm{CH}=$ protons trans to $\mathrm{NHC}$ and those trans to the $\mathrm{N}$-donor were observed. Alternatively, ${ }^{1} \mathrm{H}$ NMR spectra of $\mathrm{CD}_{2} \mathrm{Cl}_{2}$ solutions of complexes $\mathbf{3 b}$ and $\mathbf{3} \mathbf{c}$ do not show significant line broadening up to $55{ }^{\circ} \mathrm{C}$ and no exchange cross-peaks are observed in their corresponding ${ }^{1} \mathrm{H},{ }^{1} \mathrm{H}$-EXSY spectra $\left(50{ }^{\circ} \mathrm{C}\right)$, suggesting that the dynamic behavior observed for 3a in $\mathrm{CD}_{2} \mathrm{Cl}_{2}$ is absent in the case of $\mathbf{3 b}$ and $\mathbf{3} \mathbf{c}$. Hence, the fluxional behavior of 3a can be attributed to the interconversion of the two limiting forms resulting from the inversion of the chelate ring through the $\mathrm{C}-\mathrm{Rh}-\mathrm{N}$ coordination plane (Scheme 3$){ }^{26}$ In addition, since solid state $\mathrm{Rh}-\mathrm{N}$ distances are significantly longer in $\mathbf{3} \mathbf{c}$ than in $\mathbf{3 a}$, pyridine decoordination should be easier for the former complex, and consequently the $\mathrm{CH}_{2}$ bridge flipping in 3a may occur in $\mathrm{CD}_{2} \mathrm{Cl}_{2}$ without decoordination of the $\mathrm{N}$-donor fragment.

Scheme 3. Proposed Dynamic Behavior of Complexes 3

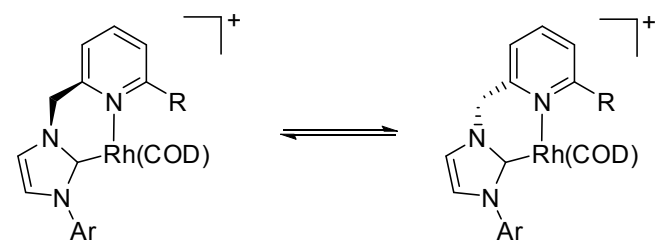

Table 2. Thermodynamic Parameters for the Dynamic Behaviour of Complexes $3 a$ and $3 b^{a}$

\begin{tabular}{ccccc}
\hline & Solvent & $\begin{array}{c}\Delta H^{*} \\
\left(\mathrm{Kcal} \mathrm{mol}^{-1}\right)\end{array}$ & $\begin{array}{c}\Delta S^{\star} \\
\left(\mathrm{cal} \mathrm{mol}^{-1}\right)\end{array}$ & $\begin{array}{c}\Delta G^{\ddagger} 300 \\
\left(\mathrm{Kcal} \mathrm{mol}^{-1}\right)\end{array}$ \\
\hline 3a & $\mathrm{CD}_{2} \mathrm{Cl}_{2}$ & $11.4(1.6)$ & $-12.8(5.4)$ & $15.3(0.3)$ \\
3a & $\mathrm{CD}_{3} \mathrm{CN}$ & $10.1(0.7)$ & $-9.5(2.7)$ & $12.9(0.9)$ \\
3b & $\mathrm{CD}_{3} \mathrm{CN}$ & $7.4(1.3)$ & $-28.6(4.5)$ & $16.0(0.1)$ \\
\hline \multicolumn{4}{c}{ Estimated standard deviations in parenthesis }
\end{tabular}

In contrast, in the presence of coordinating solvents, facile pyridine decoordination can be expected. ${ }^{27}$ Addition of increasing amounts of $\mathrm{MeCN}$ (2-200 equiv) to $\mathrm{CD}_{2} \mathrm{Cl}_{2}$ solutions of $\mathbf{3 b}$ produces significant broadening of the signals caused by the COD olefinic hydrogens and the $\mathrm{CH}_{2}$ protons of 
the picolyl-NHC ligand in the ${ }^{1} \mathrm{H}$ NMR spectra. Thus, the dynamic process for 3a-c in $\mathrm{CD}_{3} \mathrm{CN}$ has also been studied by VT- ${ }^{1} \mathrm{H}$ NMR spectroscopy. At room temperature, the ${ }^{1} \mathrm{H}$ NMR spectrum of 3a is characterized by the presence of a broad signal for the $\mathrm{CH}_{2}$ bridge and two broad signals for the $\mathrm{CH}=$ hydrogens, in agreement with a slow interconversion between the two limiting isomers of the complex (Scheme 3). Lineshape analysis of the ${ }^{1} \mathrm{H}$ NMR spectra registered in the temperature range between -35 and $50{ }^{\circ} \mathrm{C}$ indicates that the energy barrier for the dynamic process in $\mathrm{CD}_{3} \mathrm{CN}$ is lower than in $\mathrm{CD}_{2} \mathrm{Cl}_{2}$ (Table 2). In addition, VT- ${ }^{1} \mathrm{H}$ NMR spectroscopy in $\mathrm{CD}_{3} \mathrm{CN}$ of $\mathbf{3 b}$ shows that a similar dynamic behavior is operative for this complex, although the coalescence temperature was not reached at the higher studied temperature $\left(70{ }^{\circ} \mathrm{C}\right)$. Also, the ${ }^{1} \mathrm{H},{ }^{1} \mathrm{H}-\mathrm{EXSY}$ of $\mathbf{3 a}$ and $\mathbf{3 b}$ in $\mathrm{CD}_{3} \mathrm{CN}$ only shows pairwise cross-peaks for the olefinic protons of the same $\mathrm{CH}=\mathrm{CH}$ moiety. Therefore, the fluxionality shown by complex $\mathbf{3 b}$, which is not observable in $\mathrm{CD}_{2} \mathrm{Cl}_{2}$, as well as the lower barrier obtained for $\mathbf{3 a}$ in $\mathrm{CD}_{3} \mathrm{CN}$ may be ascribed to a fast interconversion between the two limiting isomers facilitated by the lability of the picolyl fragment. Moreover, the found negative entropy values suggest an associative mechanism involving the coordination of $\mathrm{CD}_{3} \mathrm{CN}$.

Alternatively, the dynamic behavior in $\mathrm{CD}_{3} \mathrm{CN}$ of the more sterically encumbered complex $\mathbf{3 c}$ differs from that of $\mathbf{3 a}$ and 3b, as demonstrated by VT- ${ }^{1} \mathrm{H}$ NMR spectroscopy. The initial AX system observed for the methylene protons of the picolylNHC ligand at low temperature is gradually converted to an $\mathrm{AB}$ system upon raising the temperature, while the signal from the $\mathrm{CH}=$ moieties broadens. Further heating of the sample makes the $\mathrm{CH}_{2}$ protons equivalent, suggesting that pyridine fragment decoordination occurs leading to a $\kappa^{1}-\mathrm{C}$ coordination of the ligand.

Overall, these studies point out to the hemilabile character of the pyridine fragment when other donating species (i.e. $\mathrm{MeCN}$ ) are present, and demonstrate the ability of the ligands to exhibit both $\kappa^{1}-\mathrm{C}$ and $\kappa^{2}-\mathrm{C}, \mathrm{N}$ coordination modes.

Catalyst Optimization and Scope. NHC-rhodium catalysts containing $\mathrm{N}$-donor functionalities have provided good levels of activity in the hydrosilylation of alkynes, although low to moderate selectivities have usually been obtained. ${ }^{15,16}$ Thus, the catalytic performance of $\mathrm{Rh}$ complexes $\mathbf{3}$ was examined in the addition of silanes to terminal alkynes. Reaction of ${ }^{n} \mathrm{Pr}_{3} \mathrm{SiH}$ with phenylacetylene in $\mathrm{CD}_{2} \mathrm{Cl}_{2}$ catalyzed by $\mathbf{3 a}$ yielded the corresponding $\beta-(E)$-alkenylsilane accompanied by lower amounts (15\%) of the Markovnikov silane addition product (Table 3, entry 1). With the exception of the NHC wingtip, the NHC ligand of complex $\mathbf{3 a}$ is structurally similar to that employed by Peris et al., which showed a preference for the formation of the $(Z)$-isomer. This result suggests that the absence of the chloride ligand is beneficial for achieving high selectivity towards the (E)-vinylsilane. Also, the level of stereoselectivity obtained with complex $\mathbf{3 a}$ prompted us to examine the catalytic performance of the other complexes. Thus, the reaction with $\mathbf{3 b}$ led to a slight increase of the selectivity towards the $(E)$-vinylsilane, while the catalyst derived from $3 \mathbf{c}$ completed the reaction with an exquisite regio- and stereoselectivity (entries 2 and 3 ), ${ }^{28}$ evidencing a significant influence of the size of the hemilabile ligand fragment on the $E / \alpha$ ratio. ${ }^{29}$ Follow-up of the reaction in $\mathrm{CD}_{2} \mathrm{Cl}_{2}$ by ${ }^{1} \mathrm{H} \mathrm{NMR}$ spectroscopy showed that the $E / \alpha$ ratio remained practically constant during the reaction course, suggesting that the $(Z)$-vinylsilane is not an intermediate in the formation of the $(E)$-olefin or that there is not a significant accumulation of this isomer. In addition, unlike with previously studied Rh-NHC catalysts, ${ }^{16 a}$ formation of other products such as silylacetylenes, resulting from the dehydrogenative silylation of the alkyne, or triphenylbenzenes, formed by trimerization of phenylacetylene, were not observed.

Examination of other solvents showed that there is not a marked influence of the reaction media on the selectivity, although the catalyst activity is somewhat affected (entries 47). Trace amounts of acetylene dimerization and cyclotrimerization were observed by GC-MS analysis when THF was employed as solvent, whereas some polymerization of phenylacetylene was evidenced when using $\mathrm{MeCN}$ and ${ }^{t} \mathrm{BuOH}$. Interestingly, in $\mathrm{CD}_{2} \mathrm{Cl}_{2}$ the substrate-to-catalyst ratio could be increased without erosion of the selectivity, providing TOF values of up to $500 \mathrm{~h}^{-1}$ at $\mathrm{S} / \mathrm{C}$ ratio of 1000 , and $206 \mathrm{~h}^{-1}$ at $\mathrm{S} / \mathrm{C}$ ratio of 5000 (entries 8 and 9).

Having determined that complex $\mathbf{3 c}$ provides the highest selectivity among the series of $\mathrm{Rh}$ complexes, other silanes were tested in the hydrosilylation of phenylacetylene (Table 4). Good activity and selectivity were observed in the addition of $\mathrm{PhMe}_{2} \mathrm{SiH}$ and 1,4-bis-(dimethylsilyl)benzene (entries 1 and 2). Also, since vinylalcoxy- and vinylsiloxysilanes are versatile substrates in organic synthesis, particularly in Hiyama cross-coupling reactions, ${ }^{\text {Id, } 1 \mathrm{e}, 1 \mathrm{~h}, 1 \mathrm{i}}$ the addition of (EtO) $)_{3} \mathrm{SiH}$ and (TMSO) $)_{3} \mathrm{SiH}$ was examined. In both cases the selectivity was high, although the reaction with the hydrosiloxane was more sluggish. It should be noted that a marked decrease of $(E)$-selectivity for heteroatom substituted silanes is usually observed with $\mathrm{Rh}$ and Pt catalysts. ${ }^{2 \mathrm{~d}, 3 \mathrm{~b}, 8,12}$

Next, the hydrosilylation of a series of acetylenes was examined using two representative silanes, ${ }^{n} \mathrm{Pr}_{3} \mathrm{SiH}$ and (EtO) $)_{3} \mathrm{SiH}$ (Table 5). Reactions of substituted phenylacetylenes with electron-donor and -withdrawings groups yielded the corresponding $(E)$-vinylsilanes with high selectivity ( $\geq 96 \%$ ) (entries $1-8$ ). As previously reported, the regioselectivity obtained with the hydroalcoxysilane is slightly lower than that of ${ }^{n} \mathrm{Pr}_{3} \mathrm{SiH}$, although the difference observed is less pronounced than with other catalytic systems. ${ }^{2 \mathrm{~d}, 3 \mathrm{~b}, 8,12}$

Hex-1-yne was chosen as an example of an alkyl-substituted alkyne, and their reactions with ${ }^{n} \mathrm{Pr}_{3} \mathrm{SiH}$ and $(\mathrm{EtO})_{3} \mathrm{SiH}$ catalyzed by $3 \mathbf{c}$ proceeded with good conversions and $(E)$ selectivities higher than $96 \%$ (entries 9 and 10). Also, it is worth noting that isomerization of the vinylsilane to the corresponding allylsilane, a process previously observed with $\mathrm{Pt}$ and $\mathrm{Rh}$ catalysts in the hydrosilylation of alkyl-substituted acetylenes is not observed. ${ }^{3 \mathrm{a}, 6 \mathrm{~b}, 16 \mathrm{a}, 16 \mathrm{~b}}$ However, the catalyst seems to be sensitive to steric effects since no reactivity was observed in the reaction of 3,3-dimethyl-butyne with ${ }^{n} \mathrm{Pr}_{3} \mathrm{SiH}$.

Furthermore, the catalytic system is compatible with a number of functional groups. For example, hydrosilylation of enynes, both with terminal and internal $\mathrm{C}=\mathrm{C}$ bonds, occurs chemoselectively at the triple C-C bond (entries 11-14). Also, the hydrosilylation of heteroatom functionalized alkynes was examined. Hydrosilane addition to propargylic alcohol occurs at the triple bond with high $(E)$-selectivity, while no silylation of the oxigen atom was observed (entries 15-16). ${ }^{30}$ Finally, the presence of potentially coordinating sulfur atoms did not 
interfere with the hydrosilylation although a sluggish reaction was observed with ${ }^{n} \mathrm{Pr}_{3} \mathrm{SiH}$ (entries 17-18).

Table 3. Hydrosilylation of Phenylacetylene with ${ }^{n} \mathrm{Pr}_{3} \mathrm{SiH}$ Catalyzed by Complexes $3^{a}$

\begin{tabular}{cccccc}
\hline Entry & Catalyst & $\mathrm{S} / \mathrm{C}$ & Solvent & ${\text { Yield }(\%)^{b}}^{b}$ & $E / \alpha$ ratio \\
\hline 1 & 3a & 200 & $\mathrm{CD}_{2} \mathrm{Cl}_{2}$ & $100(4 \mathrm{~h})$ & $85 / 15$ \\
2 & 3b & 200 & $\mathrm{CD}_{2} \mathrm{Cl}_{2}$ & $100(4 \mathrm{~h})$ & $89 / 11$ \\
3 & 3c & 200 & $\mathrm{CH}_{2} \mathrm{Cl}_{2}$ & $100(2 \mathrm{~h})$ & $99 / 1$ \\
$4^{c}$ & $\mathbf{3 c}$ & 200 & $\mathrm{THF}$ & $99(2 \mathrm{~h})$ & $99 / 1$ \\
$5^{d}$ & $\mathbf{3 c}$ & 200 & $\mathrm{MeCN}$ & $87(2 \mathrm{~h})$ & $99 / 1$ \\
$6^{d}$ & 3c & 200 & $t-\mathrm{BuOH}$ & $97(2 \mathrm{~h})$ & $99 / 1$ \\
7 & 3c & 200 & $2 \mathrm{Me}-\mathrm{THF}$ & $81(2 \mathrm{~h})$ & $98 / 2$ \\
8 & 3c & 1000 & $\mathrm{CD}_{2} \mathrm{Cl}_{2}$ & $100(2 \mathrm{~h})$ & $99 / 1$ \\
9 & 3c & 5000 & $\mathrm{CD}_{2} \mathrm{Cl}_{2}$ & $>99(24 \mathrm{~h})$ & $99 / 1$ \\
\hline
\end{tabular}

${ }^{a}$ Reactions were carried out at $60{ }^{\circ} \mathrm{C}$ (oil bath), using 0.28 mmol of phenylacetylene and $0.31 \mathrm{mmol}$ of ${ }^{n} \mathrm{Pr}_{3} \mathrm{SiH}$. [Phenylacetylene] $=0.6 \mathrm{M}$. Yield and $E / \alpha$ ratio were determined by ${ }^{1} \mathrm{H}$ NMR spectroscopy or GC-MS using mesitylene as internal standard. ${ }^{b}$ Reaction time in parenthesis. ${ }^{c}$ Oligomerization of phenylacetylene was detected by GC-MS. ${ }^{d}$ Formation of polyphenylacetylene was observed.

Table 4. Hydrosilylation of Phenylacetylene Catalyzed by $3 \mathrm{c}^{a}$

\begin{tabular}{ccccc}
\hline Entry & Silane & $\mathrm{S} / \mathrm{C}$ & ${\text { Yield }(\%)^{b}}^{b}$ & $E / \alpha$ ratio \\
\hline 1 & $\mathrm{PhMe}_{2} \mathrm{SiH}$ & 2000 & $100(4 \mathrm{~h})$ & $97 / 3$ \\
$2^{c}$ & $1,4-\left(\mathrm{HSiMe}_{2}\right)_{2} \mathrm{C}_{6} \mathrm{H}_{4}$ & 2000 & $99(4 \mathrm{~h})$ & $97 / 3$ \\
3 & $(\mathrm{EtO})_{3} \mathrm{SiH}$ & 2000 & $100(4 \mathrm{~h})$ & $96 / 4$ \\
4 & $(\mathrm{TMSO})_{3} \mathrm{SiH}$ & 500 & $100(4 \mathrm{~h})$ & $99 / 1$ \\
\hline
\end{tabular}

${ }^{a}$ Reactions were carried out at $60{ }^{\circ} \mathrm{C}$ (oil bath) in $\mathrm{CD}_{2} \mathrm{Cl}_{2}$ using $0.28 \mathrm{mmol}$ of phenylacetylene and $0.31 \mathrm{mmol}$ of silane. [Phenylacetylene] $=0.6 \mathrm{M}$. Yield and $E / \alpha$ ratios were determined by ${ }^{1} \mathrm{H}$ NMR spectroscopy. ${ }^{b}$ Reaction time in parenthesis. ${ }^{c} 0.56$ mmol of phenylacetylene was used.
Table 5. Hydrosilylation of Acetylenes with ${ }^{n} \mathrm{Pr}_{3} \mathrm{SiH}$ and (EtO) $)_{3} \mathrm{SiH}$ Catalyzed by $3 \mathrm{c}^{a}$

\begin{tabular}{|c|c|c|c|c|c|}
\hline Entry & Alkyne & Silane & $\mathrm{S} / \mathrm{C}$ & $\begin{array}{l}\text { Yield } \\
(\%)^{b}\end{array}$ & $\begin{array}{l}E / \alpha \\
\text { ratio }\end{array}$ \\
\hline 1 & \multirow{2}{*}{$00-\square$} & ${ }^{n} \mathrm{Pr}_{3} \mathrm{SiH}$ & 500 & $\begin{array}{c}100 \\
(4 \mathrm{~h})\end{array}$ & $>99 /-$ \\
\hline 2 & & $(\mathrm{EtO})_{3} \mathrm{SiH}$ & 500 & $\begin{array}{c}100 \\
(4 \mathrm{~h})\end{array}$ & $96 / 4$ \\
\hline 3 & & ${ }^{n} \mathrm{Pr}_{3} \mathrm{SiH}$ & 500 & $\begin{array}{c}93 \\
(4 \mathrm{~h})\end{array}$ & $>99 /{ }^{c}$ \\
\hline 4 & & $(\mathrm{EtO})_{3} \mathrm{SiH}$ & 500 & $\begin{array}{c}94 \\
(4 \mathrm{~h}) \\
\end{array}$ & $98 / 2$ \\
\hline 5 & & ${ }^{n} \mathrm{Pr}_{3} \mathrm{SiH}$ & 500 & $\begin{array}{c}98 \\
(4 \mathrm{~h})\end{array}$ & $98 / 2$ \\
\hline 6 & & $(\mathrm{EtO})_{3} \mathrm{SiH}$ & 500 & $\begin{array}{c}98 \\
(4 \mathrm{~h})\end{array}$ & $97 / 3$ \\
\hline 7 & & ${ }^{n} \mathrm{Pr}_{3} \mathrm{SiH}$ & 500 & $\begin{array}{c}87 \\
(8 \mathrm{~h})\end{array}$ & $98 / 2$ \\
\hline 8 & & $(\mathrm{EtO})_{3} \mathrm{SiH}$ & 500 & $\begin{array}{c}100 \\
(4 \mathrm{~h})\end{array}$ & $97 / 3$ \\
\hline 9 & & ${ }^{n} \mathrm{Pr}_{3} \mathrm{SiH}$ & 200 & $\begin{array}{c}97 \\
(4 \mathrm{~h})\end{array}$ & $99 / 1$ \\
\hline 10 & 1-Hexyne & $(\mathrm{EtO})_{3} \mathrm{SiH}$ & 500 & $\begin{array}{c}91 \\
(4 \mathrm{~h})\end{array}$ & $96 / 4$ \\
\hline 11 & & ${ }^{n} \mathrm{Pr}_{3} \mathrm{SiH}$ & 500 & $\begin{array}{c}100 \\
(4 \mathrm{~h})\end{array}$ & $99 / 1$ \\
\hline 12 & & $(\mathrm{EtO})_{3} \mathrm{SiH}$ & 500 & $\begin{array}{c}100 \\
(4 \mathrm{~h})\end{array}$ & $96 / 4$ \\
\hline 13 & & ${ }^{n} \mathrm{Pr}_{3} \mathrm{SiH}$ & 500 & $\begin{array}{c}100 \\
(4 \mathrm{~h})\end{array}$ & $99 / 1$ \\
\hline 14 & & $(\mathrm{EtO})_{3} \mathrm{SiH}$ & 500 & $\begin{array}{r}100 \\
(4 \mathrm{~h})\end{array}$ & $d$ \\
\hline $15^{e}$ & & ${ }^{n} \mathrm{Pr}_{3} \mathrm{SiH}$ & 5000 & $\begin{array}{c}100 \\
(4 \mathrm{~h})\end{array}$ & $>99 /-$ \\
\hline 16 & & $(\mathrm{EtO})_{3} \mathrm{SiH}$ & 500 & $\begin{array}{c}95 \\
(4 \mathrm{~h})\end{array}$ & $83 / 17$ \\
\hline 17 & & ${ }^{n} \mathrm{Pr}_{3} \mathrm{SiH}$ & 500 & $\begin{array}{c}26 \\
(4 \mathrm{~h})^{f}\end{array}$ & $99 / 1$ \\
\hline 18 & & $(\mathrm{EtO})_{3} \mathrm{SiH}$ & 500 & $\begin{array}{c}100 \\
(4 \mathrm{~h})\end{array}$ & $95 / 5$ \\
\hline
\end{tabular}

${ }^{a}$ Reactions were carried out at $60{ }^{\circ} \mathrm{C}$ (oil bath) in $\mathrm{CD}_{2} \mathrm{Cl}_{2}$ using $0.28 \mathrm{mmol}$ of acetylene and $0.31 \mathrm{mmol}$ of ${ }^{n} \mathrm{Pr}_{3} \mathrm{SiH}$ or $(\mathrm{EtO})_{3} \mathrm{SiH}$. [Alkyne] $=0.6 \mathrm{M}$. Yield and $E / \alpha$ ratios were determined by ${ }^{1} \mathrm{H}$ NMR spectroscopy. ${ }^{b}$ Reaction time in parenthesis. ${ }^{c}$ Minor amounts, less than $2 \%$, of the $\beta$-(Z)-vinylsilane were observed. ${ }^{d}$ $\beta-(E) / \beta-(Z) / \alpha$ ratio $=91 / 2 / 7 .{ }^{e}[$ Alkyne $]=0.3 \mathrm{M} .{ }^{f}$ Longer reaction time $(72 \mathrm{~h})$ did not increase conversion. 
Mechanistic Considerations. The commonly accepted steps for the hydrosylilation of alkynes are based on the Chalk-Harrod mechanism for alkene hydrosilylation, ${ }^{2 \mathrm{~d}, 31}$ which involves the oxidative addition of the silane $\mathrm{Si}-\mathrm{H}$ bond to the metal, migratory insertion of the coordinated alkyne into the $\mathrm{M}-\mathrm{H}$ fragment and reductive elimination of the vinyl and silyl ligands. For some catalytic systems, however, a modified Chalk-Harrod mechanism has been proposed to explain the formation of the $Z$ derivatives and dehydrogenative silylation products. $^{2 \mathrm{~d}}$ In this alternative mechanism, alkyne insertion takes place into the Rh-Si bond, which might be followed by cis/trans isomerization of the resulting vinyl complex through the involvement of metallacyclopropene ${ }^{6 \mathrm{a}, 6 \mathrm{~b}}$ or zwitterionic carbene $^{11}$ species before the reductive elimination step.

To shed light on the mechanism of the reactions catalyzed by complexes $\mathbf{3}$, the hydrosilylation of phenylacetylene with ${ }^{n} \mathrm{Pr}_{3} \mathrm{SiH}$ catalyzed by $20 \mathrm{~mol} \%$ of complex $\mathbf{3 b}$ in $\mathrm{CD}_{2} \mathrm{Cl}_{2}$ was followed up by ${ }^{1} \mathrm{H}$ NMR spectroscopy. Interestingly, no intermediates, to the detection limit of the ${ }^{1} \mathrm{H}$ NMR spectroscopy, were observed since the signals corresponding to the $\mathrm{Rh}$ precursor appeared unchanged. This observation suggests that the catalyst is formed in a very low concentration, below the NMR detection limit, from the catalyst precursor $\mathbf{3 b}$.

Next, the reactivity of the Rh precursors with the coupling partners was studied individually. Addition of a slight excess of phenylacetylene (5 equiv) to a solution of $\mathbf{3 b}$ in $\mathrm{CD}_{2} \mathrm{Cl}_{2}$ or $\mathrm{CD}_{3} \mathrm{CN}$ produces no changes, to the detection limit of the technique, in the signals of the ${ }^{1} \mathrm{H}$ NMR spectrum of the Rh complex whereas the resonances of phenylacetylene gradually disappear and new broad signals are observed in the aromatic region. These changes are accompanied by the formation of an insoluble red solid resulting from alkyne polymerization. ${ }^{32}$

On the other hand, prolonged heating of a solution of $\mathbf{3 b}$ and triethoxysilane (15 equiv) in $\mathrm{CD}_{2} \mathrm{Cl}_{2}$ yields complex 4 (Scheme 4). A similar reaction outcome is observed when tripropylsilane is employed, however reactions are accompanied by abundant formation of a black metallic precipitate. In the ${ }^{1} \mathrm{H}$ NMR spectrum of 4 registered in $\mathrm{CD}_{2} \mathrm{Cl}_{2}$, four different signals between 3.0 and $4.8 \mathrm{ppm}$ attributable to the olefinic protons of the COD ligand are observed, as well as two doublets for the diastereotopic protons of the $\mathrm{CH}_{2}$ bridge appearing at 5.74 and $6.77 \mathrm{ppm}$ $\left({ }^{2} J_{\mathrm{HH}}=15.7 \mathrm{~Hz}\right)$ that reflects a hindered rotation of the NHC ligand around the $\mathrm{C}^{2}(\mathrm{NHC})-\mathrm{Rh}$ bond. The ${ }^{13} \mathrm{C}\left\{{ }^{1} \mathrm{H}\right\}$ NMR spectrum shows one doublet signal for the $\mathrm{C}^{2}(\mathrm{NHC})$ carbon at $\delta=184 \mathrm{ppm}\left(J_{\mathrm{CRh}}=52 \mathrm{~Hz}\right)$, and two pairs of doublets for the olefinic carbons, one in the range $68-69 \mathrm{ppm}\left(J_{\mathrm{CRh}}=14 \mathrm{~Hz}\right)$ and other at $96-98 \mathrm{ppm}\left(J_{\mathrm{CRh}}=7 \mathrm{~Hz}\right)$. Electrospray mass spectroscopy investigation of $\mathbf{4}$ produced peaks consistent with the expected ion $[M-\mathrm{Cl}]^{+}$. The structural assignment for complex 4, having a coordinated NHC fragment and a dangling pyridyl moiety, is further supported by comparison of their NMR data with those reported for similar complexes by Liu and coworkers. 2 a Testing of complex 4 in the hydrosilylation of phenylacetylene with ${ }^{n} \mathrm{Pr}_{3} \mathrm{SiH}(\mathrm{S} / \mathrm{C}=100$, $60{ }^{\circ} \mathrm{C}, \mathrm{CD}_{2} \mathrm{Cl}_{2}$ ) resulted in a significantly different catalytic activity and product distribution to that provided by $\mathbf{3 b}$, since a product ratio of $E / Z / \alpha /$ styrene/silylacetylene $=84 / 3 / 5 / 3 / 5$ was obtained ( $81 \%$ conv., $24 \mathrm{~h})$, in line with the negligible formation of $\mathbf{4}$ from $\mathbf{3 b}$ under catalytic conditions and making evident the beneficial effect of using a catalyst precursor with a non-coordinating counteranion.

Scheme 4. Reaction of Complex $3 b$ with $\mathrm{HSi}(\mathrm{OEt})_{3}$ in $\mathrm{CH}_{2} \mathrm{Cl}_{2}$

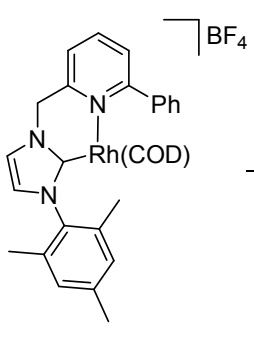

$3 b$

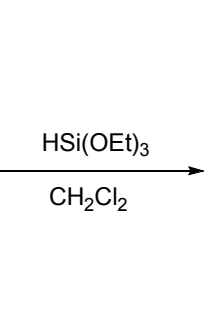

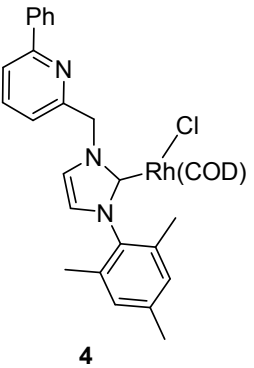

Interestingly, alternative heating of $\mathbf{3 c}$ in $\mathrm{CD}_{3} \mathrm{CN}$ with an excess of triethoxysilane shows the formation of a new species that has been assigned to the silyl hydrido Rh complex $\mathbf{5}$, resulting from the formal activation of the silane $\mathrm{Si}-\mathrm{H}$ bond (Scheme 5). GC-MS analysis of the reaction mixture shows the formation of cyclooctene as well as $\mathrm{Si}(\mathrm{OEt})_{4}$ and minor amounts of other unidentified silicon species. The ${ }^{1} \mathrm{H}$ NMR spectrum of the silylrhodium hydride $\mathbf{5}$ shows the appearance of a doublet at $-17.46 \mathrm{ppm}\left({ }^{1} J_{\mathrm{HRh}}=30.8 \mathrm{~Hz}\right)$ attributable to the $\mathrm{Rh}-\mathrm{H}$ functionality, and two doublets at 5.36 and $6.00 \mathrm{ppm}$ $\left({ }^{2} J_{\mathrm{HH}}=14.8 \mathrm{~Hz}\right)$ for the diastereotopic protons of the $\mathrm{CH}_{2}$ linker. The signals corresponding to the silyl ligand $\mathrm{Si}\left(\mathrm{OCH}_{2} \mathrm{CH}_{3}\right)_{3}$ appear at 0.99 and $3.60 \mathrm{ppm}$ as a triplet and a quartet $\left({ }^{3} J_{\mathrm{HH}}=7.0 \mathrm{~Hz}\right)$, respectively. The ${ }^{13} \mathrm{C}\left\{{ }^{1} \mathrm{H}\right\} \mathrm{NMR}$ spectrum shows the signal corresponding to the carbenic carbon at $173.6 \mathrm{ppm}$ as a doublet $\left({ }^{1} J_{\mathrm{CRh}}=54 \mathrm{~Hz}\right)$. In addition, the 2D NMR heteronuclear correlation ${ }^{1} \mathrm{H},{ }^{29} \mathrm{Si} \mathrm{HMBC}$ exhibits a cross-peak doublet signal at $-34.3 \mathrm{ppm}\left({ }^{1} J_{\mathrm{SiRh}}=62 \mathrm{~Hz}\right)$ between the hydride and the silicon atom of $\mathbf{5}$. Finally, an intense cross-peak was observed in the ${ }^{1} \mathrm{H},{ }_{1}^{1} \mathrm{H}$ NOESY experiment between the $\mathrm{Rh}-\mathrm{H}$ and $\mathrm{SiOCH}_{2} \mathrm{CH}_{3}$ hydrogens suggesting a cis arrangement for the hydrido and silyl ligands. Analysis of 5 by ESI-MS provides a peak at $\mathrm{m} / \mathrm{z}=680$ attributable to the ion $\left[M-2 \mathrm{MeCN}-\mathrm{BF}_{4}\right]^{+}$. In support for the proposed structure of $\mathbf{5}$, it should be mentioned that an analogous Ir complex has been previously reported by Peris and coworkers. ${ }^{6 \mathrm{~d}}$ Finally, in order to examine the catalytic performance of 5, a 6-fold equimolar amount of triethoxysilane and phenylacetylene was added to a solution in $\mathrm{CD}_{2} \mathrm{Cl}_{2}$ of $\mathbf{5}$ yielding the hydrosilylation product with a $E / \alpha$ ratio of 96:4 along with the starting complex, and therefore suggesting that $\mathbf{5}$ is involved in the catalytic cycle.

\section{Scheme 5. Reaction of Complex $3 \mathrm{c}$ with $\mathrm{HSi}(\mathrm{OEt})_{3}$ in $\mathrm{CD}_{3} \mathrm{CN}$}
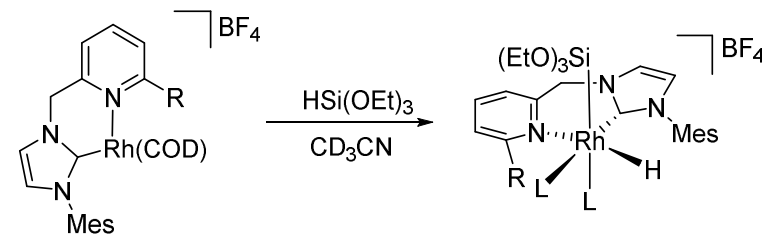

$3 c\left(\mathrm{R}=2,6-(\mathrm{MeO})_{2}-\mathrm{C}_{6} \mathrm{H}_{3}\right)$

$5 \quad \mathrm{~L}=\mathrm{CD}_{3} \mathrm{CN}$ 
Next, it was deemed to study the influence of electronic effects on the rate of hydrosilane addition to substituted phenylacetylenes. Preliminary experiments showed significantly faster reactions for arylalkynes containing electron-donating groups than for alkynes having electronwithdrawing substituents. However, this observation might be caused by intrinsically different catalytic cycle rates or be due to differences in precatalyst activation if the alkyne plays a role on the formation of the active species, for example by promoting the decoordination of the pyridine fragment of the picolyl-NHC ligand in analogy to the observed influence of $\mathrm{MeCN}$ on the dynamic properties of complexes 3 (see above). In order to eliminate the influence of the catalyst formation step on the reaction rate, a series of competition reactions involving the hydrosilylation of equimolar amounts of phenylacetylene and $\mathrm{X}-\mathrm{C}_{6} \mathrm{H}_{4} \mathrm{C} \equiv \mathrm{CH}(\mathrm{X}=p-\mathrm{MeO}, p-\mathrm{Br}, m-\mathrm{Cl})$ with ${ }^{n} \mathrm{Pr}_{3} \mathrm{SiH}$ were investigated (Scheme 6). In all the experiments, both acetylenes reacted at the same rate, demonstrating that the catalytic reactions are insensitive to the electronic nature of the alkyne.

The study of kinetic isotope effects (KIEs) provides a straightforward method to obtain relevant mechanistic information and support the proposal of reaction mechanisms. ${ }^{33}$ Thus, catalytic reactions with selectively deuterated substrates were performed. From the reaction of phenylacetylene (1.0 equiv) with ${ }^{n} \mathrm{Pr}_{3} \mathrm{SiH}$ (1.0 equiv) and ${ }^{n} \operatorname{Pr}_{3} \operatorname{SiD}$ (1.0 equiv) (Scheme 7), a $K_{\mathrm{H}} / K_{\mathrm{D}}=1.0$ was found, suggesting that oxidative addition of the hydrosilane is not involved in the rate-determining step. Alternatively, for the reaction of $\mathrm{C}_{6} \mathrm{H}_{5} \mathrm{C} \equiv \mathrm{CH}$ (1.0 equiv) and $\mathrm{C}_{6} \mathrm{H}_{5} \mathrm{C} \equiv \mathrm{CD}$ (1.0 equiv) with ${ }^{n} \mathrm{Pr}_{3} \mathrm{SiH}$ (1.0 equiv) (Scheme 8 ), a secundary kinetic isotope effect $K_{\mathrm{H}} / K_{\mathrm{D}}=1.1$ was determined. Also, from the study of the geometry of the obtained deuterated products in these experiments, syn addition of the silane to the alkyne was evidenced.

Scheme 6. Determination of Electronic Effects on the Hydrosilylation Rates

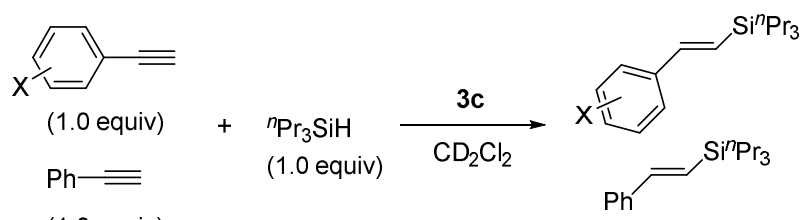

(1.0 equiv)

$\mathrm{X}=p-\mathrm{MeO}, p-\mathrm{Br}, m-\mathrm{Cl}$

Scheme 7. Determination of KIE using Deuterated Silane

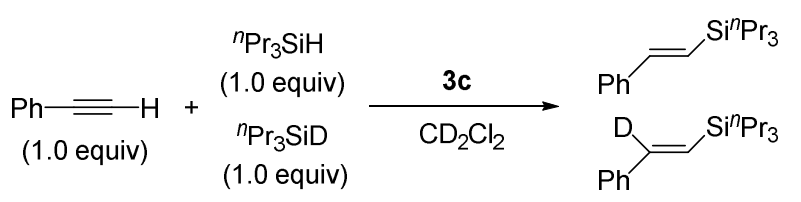

$K_{H} / K_{D}=1.0$
Scheme 8. Determination of KIE using Deuterated Alkyne

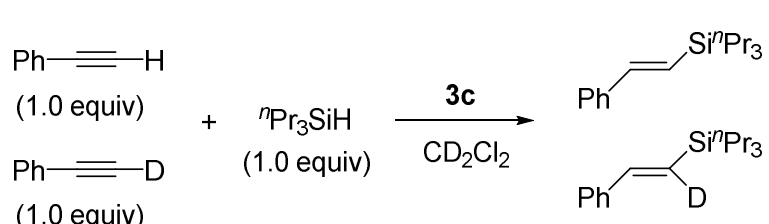

(1.0 equiv)

$$
K_{\mathrm{H}} / K_{\mathrm{D}}=1.1
$$

Although further mechanistic studies are required, the assumption of Chalk-Harrod mechanisms for the hydrosilylation of alkynes catalyzed by Rh complexes 3 seems plausible based on the above experimental data and literature precedents (Figure 3). After initial formation of a hydrido-silyl Rh species A (i.e. 5), alkyne coordination should take place to yield B. From this intermediate, two different outcomes involving the migratory insertion of the alkyne into the $\mathrm{Rh}-\mathrm{H}$ bond are possible depending on the orientation of the insertion step $(1,2$ or 2,1). An alkyne 1,2-insertion would lead to vinyl $\mathrm{Rh}$ species $\mathbf{C}^{\boldsymbol{H}}(E)$, that after reductive elimination and activation of a new silane molecule, would regenerate $\mathbf{A}$ and afford the major $(E)$-vinylsilane derivative. Alternative 2,1insertion into the $\mathrm{Rh}-\mathrm{H}$ bond would produce $\mathbf{C}^{\boldsymbol{H}}(\alpha)$, which ultimately would yield the $\alpha$-vinylsilane. Similar pathways involving intermediates $\mathbf{C}^{S i}(E)$ and $\mathbf{C}^{S i}(\alpha)$ can be regarded if, instead of the migratory insertion of the alkyne into the $\mathrm{Rh}-\mathrm{H}$ bond, the silyl group is delivered to the coordinated alkyne (modified Chalk-Harrod mechanism). Since the reaction regioselectivity is given by the migratory insertion step, analysis of intermediates $\mathbf{C}$ can provide clues about the operative mechanism. If the insertion into the $\mathrm{Rh}-\mathrm{H}$ bond is considered, formation of intermediate $\mathbf{C}^{\boldsymbol{H}}(\alpha)$ should be disfavored based on steric grounds, and an increase of the steric crowding of the pyridine fragment of the picolyl-NHC ligand would provide higher anti-Markovnikov selectivity, as observed in the reactions catalyzed by complexes 3 (Table 3 ). Alternatively, if silyl delivery to the coordinated alkyne takes place, steric hindrance should disfavor the formation of $\mathbf{C}^{S i}(E)$ over $\mathbf{C}^{S i}(\alpha)$. Hence, we hypothesized that a standard ChalkHarrod mechanism is operative with complexes 3. However, since formation of minor amounts of $(Z)$-isomers has been observed in some reactions (Table 5, entries 3 and 14), what may be explained by the partial isomerization of $\mathbf{C}^{S i}(E)$ to $\mathbf{C}^{S i}(Z)$, the occurrence of a modified Chalk-Harrod mechanism cannot be completely excluded.

\section{CONCLUSIONS}

A series of $\mathrm{Rh}(\mathrm{I})$ complexes $\mathbf{3}$ containing picolyl-NHC ligands differing in the steric crowding at the 6-position of the pyridine moiety has been synthesized, and the hemilabile nature of the $N$-donor fragment has been demonstrated by NMR spectroscopy. Complexes 3 activate the H-Si bonds of silanes to yield silyl hydrido Rh species, such as $\mathbf{5}$, that are efficient catalysts in the $(E)$-selective hydrosilylation of terminal alkynes. Although, the catalytic activities provided by these catalysts are still far from that of the very active $\operatorname{Pt}(0)$ species, to the best of our knowledge, this catalytic system is only surpassed in terms of activity by only two other rhodium(I) $(E)$-selective catalysts, ${ }^{10 \mathrm{~b}, 12 \mathrm{~b}}$ while the high selectivity towards the formation of $(E)$-vinylsilanes and wide alkyne and silane scope make these alkyne hydrosilylation catalysts of practical interest. Also, this study highlights the 
importance of ligand design for the development of selective $\mathrm{Rh}$ catalysts for the hydrosilylation of alkynes, since a significant influence of the steric hindrance of the hemilabile ligand fragment on the $E / \alpha$ ratio has been evidenced. ${ }^{29}$

\section{EXPERIMENTAL SECTION}

General Procedures. All reactions and manipulations were performed under nitrogen or argon, either in a Braun Labmaster 100 glovebox or using standard Schlenk-type techniques. All solvents were dried over appropriate drying agents and distilled under nitrogen. NMR spectra were obtained on Bruker DPX-300, DRX-400, or DRX-500 spectrometers. ${ }^{13} \mathrm{C}\left\{{ }^{1} \mathrm{H}\right\}$ and ${ }^{1} \mathrm{H}$ shifts were referenced to the residual signals of deuterated solvents. All data are reported in ppm downfield from $\mathrm{Me}_{4} \mathrm{Si}$. ESI-MS experiments were carried out in a Bruker 6000 apparatus by the Mass Spectrometry Service of the Instituto de Investigaciones Químicas. Elemental analyses were run by the Analytical Service of the Instituto de Investigaciones Químicas in a Leco CHNS-932 elemental analyzer.

Synthesis of Rh Complexes 3. A solution of the corresponding silver complex $2(0.24 \mathrm{mmol})$ and $\left[\mathrm{Rh}(\mathrm{COD})_{2}\right] \mathrm{BF}_{4}(0.094 \mathrm{~g}, 0.24$ mmol) in $\mathrm{CH}_{2} \mathrm{Cl}_{2}(8 \mathrm{~mL})$ was stirred for $4 \mathrm{~h}$. The mixture was filtered through a short pad of celite, and the solution was brought to dryness. The resulting solid was washed with $\mathrm{Et}_{2} \mathrm{O}(3 \times 10 \mathrm{~mL})$ and recrystallized from a mixture of $\mathrm{CH}_{2} \mathrm{Cl}_{2} / \mathrm{Et}_{2} \mathrm{O}$

Complex 3a. Yellow-orange solid (63\%). Anal. Calcd for $\mathrm{C}_{26} \mathrm{H}_{31} \mathrm{BF}_{4} \mathrm{~N}_{3} \mathrm{Rh}$ (\%): C 54.29; $\mathrm{H}$ 5.43; N 7.30. Found: C 54.29; $\mathrm{H}$ 5.50; N 7.09. MS (ESI, $\left.\mathrm{CH}_{2} \mathrm{Cl}_{2} / \mathrm{MeOH}\right): \mathrm{m} / z 488\left(\left[M^{+}\right]^{+}, 100\right) .{ }^{1} \mathrm{H}$ NMR ( $\left.\mathrm{CD}_{2} \mathrm{Cl}_{2}, 400 \mathrm{MHz}\right): \delta 1.75-2.48(\mathrm{~m}, 8 \mathrm{H}, 8 \mathrm{CHH} \mathrm{COD}), 2.02(\mathrm{~s}$, $\left.6 \mathrm{H}, 2 \mathrm{CH}_{3}\right), 2.38\left(\mathrm{~s}, 3 \mathrm{H}, \mathrm{CH}_{3}\right), 3.30(\mathrm{br}, 1 \mathrm{H}, \mathrm{CH}=\mathrm{COD}), 4.25(\mathrm{br}, 1 \mathrm{H}$, $\mathrm{CH}=\mathrm{COD}), 4.45(\mathrm{br}, 1 \mathrm{H}, \mathrm{CH}=\mathrm{COD}), 4.51(\mathrm{br}, 1 \mathrm{H}, \mathrm{CH}=\mathrm{COD}), 5.72$ (br d, ${ }^{2} J_{\mathrm{HH}}=13.5 \mathrm{~Hz}, 1 \mathrm{H}$, py-CHH), $6.05\left(\mathrm{br} \mathrm{d},{ }^{2} J_{\mathrm{HH}}=13.8 \mathrm{~Hz}, 1 \mathrm{H}\right.$, py-CHH), $6.81\left(\mathrm{~d},{ }^{3} J_{\mathrm{HH}}=1.8 \mathrm{~Hz}, 1 \mathrm{H}, \mathrm{H}\right.$ arom), $7.01($ br s, $1 \mathrm{H}, \mathrm{H}$ arom), 7.09 (br s, $1 \mathrm{H}, \mathrm{H}$ arom), 7.43 (ddd, ${ }^{3} J_{\mathrm{HH}}=5.8 \mathrm{~Hz},{ }^{3} J_{\mathrm{HH}}=5.8$ $\mathrm{Hz},{ }^{4} J_{\mathrm{HH}}=3.1 \mathrm{~Hz}, 1 \mathrm{H}, \mathrm{H}$ arom $), 7.59\left(\mathrm{~d},{ }^{3} J_{\mathrm{HH}}=1.8 \mathrm{~Hz}, 1 \mathrm{H}, \mathrm{H}\right.$ arom $)$, $7.95(\mathrm{~m}, 2 \mathrm{H}, 2 \mathrm{H}$ arom $), 8.35\left(\mathrm{~d},{ }^{3} \mathrm{JHH}_{\mathrm{HH}}=5.4 \mathrm{~Hz}, 1 \mathrm{H}, \mathrm{H}\right.$ arom $) .{ }^{13} \mathrm{C}\left\{{ }^{1} \mathrm{H}\right\}$ NMR ( $\mathrm{CD}_{2} \mathrm{Cl}_{2}, 101 \mathrm{MHz}$ ): $\delta 17.9$ (br s, $\left.\mathrm{CH}_{3}\right), 19.1$ (br s, $\left.\mathrm{CH}_{3}\right), 21.2$ $\left(\mathrm{CH}_{3}\right.$ ), 28.2 (br s, $\mathrm{CH}_{2} \mathrm{COD}$ ), 30.4 (br s, $\mathrm{CH}_{2} \mathrm{COD}$ ), 31.4 (br s, $\mathrm{CH}_{2}$ COD), 33.3 (br s, $\mathrm{CH}_{2} \mathrm{COD}$ ), 56.2 (py-CH ( $_{2}, 77.0$ (br m, $\mathrm{CH}=\mathrm{COD}$ ), 79.1 (br m, $\mathrm{CH}=\mathrm{COD}$ ), 97.0 (br m, $\mathrm{CH}=\mathrm{COD}$ ), 98.9 (br m, $\mathrm{CH}=$ COD), 122.7 (CH arom), 123.5 (CH arom), 125.8 (CH arom), 126.2 (CH arom), $129.0\left(\mathrm{C}_{\mathrm{q}}\right.$ arom), 129.5 (br s, $2 \mathrm{CH}$ arom), 134.9 (br s, $\mathrm{C}_{\mathrm{q}}$ arom), 135.7 (br s, $\mathrm{C}_{\mathrm{q}}$ arom), $140.0\left(\mathrm{C}_{\mathrm{q}}\right.$ arom), 140.1 ( $\mathrm{CH}$ arom), $151.3(\mathrm{CH}$ arom $), 154.5\left(\mathrm{C}_{\mathrm{q}}\right.$ arom $), 177.7\left(\mathrm{~d}, J_{\mathrm{CRh}}=52 \mathrm{~Hz}, \mathrm{C}-2\right.$ NHC).

Complex 3b. Yellow-orange solid (59\%). Anal. Calcd for $\mathrm{C}_{32} \mathrm{H}_{35} \mathrm{BF}_{4} \mathrm{~N}_{3} \mathrm{Rh}(\%)$ : C 59.01; H 5.42; N 6.45. Found: C 59.19; $\mathrm{H}$ 5.57; N 6.41. MS (ESI, $\left.\mathrm{CH}_{2} \mathrm{Cl}_{2} / \mathrm{MeOH}\right): m / z 564\left(\left[M^{+}\right]^{+}, 100\right) .{ }^{1} \mathrm{H}$ NMR ( $\left.\mathrm{CD}_{2} \mathrm{Cl}_{2}, 400 \mathrm{MHz}\right): \delta 1.23(\mathrm{~m}, 2 \mathrm{H}, 2 \mathrm{CHH} \mathrm{COD}), 1.56(\mathrm{~m}$, $1 \mathrm{H}, \mathrm{CH} \mathrm{H} \mathrm{COD}), 1.89\left(\mathrm{~s}, 3 \mathrm{H}, \mathrm{CH}_{3}\right), 2.05\left(\mathrm{~s}, 3 \mathrm{H}, \mathrm{CH}_{3}\right), 2.07(\mathrm{~m}, 4 \mathrm{H}, 4$ $\mathrm{CH} \mathrm{H} \mathrm{COD}), 2.47\left(\mathrm{~s}, 3 \mathrm{H}, \mathrm{CH}_{3}\right), 2.49(\mathrm{~m}, 2 \mathrm{H}, \mathrm{CHH} \mathrm{COD}+\mathrm{CH}=$ $\mathrm{COD}), 3.70(\mathrm{~m}, 1 \mathrm{H}, \mathrm{CH}=\mathrm{COD}), 4.03(\mathrm{~m}, 1 \mathrm{H}, \mathrm{CH}=\mathrm{COD}), 4.29(\mathrm{~m}$, $1 \mathrm{H}, \mathrm{CH}=\mathrm{COD}), 5.99\left(\mathrm{~d},{ }^{2} J_{\mathrm{HH}}=14.8 \mathrm{~Hz}, 1 \mathrm{H}\right.$, py-CHH$), 6.48\left(\mathrm{~d},{ }^{2} J_{\mathrm{HH}}\right.$ $=14.8 \mathrm{~Hz}, 1 \mathrm{H}$, py-CHH$), 6.88(\mathrm{~s}, 1 \mathrm{H}, \mathrm{H}$ arom $), 7.08(\mathrm{~s}, 1 \mathrm{H}, \mathrm{H}$ arom $)$, $7.19(\mathrm{~s}, 1 \mathrm{H}, \mathrm{H}$ arom $), 7.63\left(\mathrm{dd},{ }^{3} J_{\mathrm{HH}}=7.5 \mathrm{~Hz},{ }^{3} J_{\mathrm{HH}}=7.5 \mathrm{~Hz}, 2 \mathrm{H}, 2 \mathrm{H}\right.$ arom), $7.71\left(\mathrm{t},{ }^{3} J_{\mathrm{HH}}=7.0 \mathrm{~Hz}, 1 \mathrm{H}, \mathrm{H}\right.$ arom $), 7.76\left(\mathrm{~d},{ }^{3} J_{\mathrm{HH}}=7.0 \mathrm{~Hz}\right.$, $1 \mathrm{H}, \mathrm{H}$ arom), $7.77(\mathrm{~s}, 1 \mathrm{H}, \mathrm{H}$ arom $), 8.03\left(\mathrm{~d},{ }^{3} J_{\mathrm{HH}}=7.2 \mathrm{~Hz}, 1 \mathrm{H}, \mathrm{H}\right.$ arom), $8.07\left(\mathrm{dd},{ }^{3} J_{\mathrm{HH}}=7.5 \mathrm{~Hz},{ }^{3} J_{\mathrm{HH}}=7.5 \mathrm{~Hz}, 1 \mathrm{H}, \mathrm{H}\right.$ arom $), 8.32(\mathrm{~d}$, ${ }^{3} J_{\mathrm{HH}}=7.4 \mathrm{~Hz}, 2 \mathrm{H}, 2 \mathrm{H}$ arom $) .{ }^{13} \mathrm{C}\left\{{ }^{1} \mathrm{H}\right\} \operatorname{NMR}\left(\mathrm{CD}_{2} \mathrm{Cl}_{2}, 101 \mathrm{MHz}\right): \delta$ $17.8\left(\mathrm{CH}_{3}\right), 17.9\left(\mathrm{CH}_{3}\right), 21.3\left(\mathrm{CH}_{3}\right), 25.9\left(\mathrm{CH}_{2} \mathrm{COD}\right), 29.6\left(\mathrm{CH}_{2}\right.$

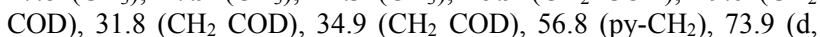
$\left.J_{\mathrm{CRh}}=12 \mathrm{~Hz}, \mathrm{CH}=\mathrm{COD}\right), 75.7\left(\mathrm{~d}, J_{\mathrm{CRh}}=14 \mathrm{~Hz}, \mathrm{CH}=\mathrm{COD}\right), 92.8(\mathrm{~d}$, $\left.J_{\mathrm{CRh}}=7 \mathrm{~Hz}, \mathrm{CH}=\mathrm{COD}\right), 100.7\left(\mathrm{~d}, J_{\mathrm{CRh}}=8 \mathrm{~Hz}, \mathrm{CH}=\mathrm{COD}\right), 123.4$ $(\mathrm{CH}$ arom), $123.7(\mathrm{CH}$ arom), $124.3(\mathrm{CH}$ arom $), 125.0(\mathrm{CH}$ arom $)$, 127.0 (2 CH arom), 128.9 (CH arom), 129.5 (3 CH arom), $131.6(\mathrm{CH}$ arom $), 135.3\left(\mathrm{C}_{\mathrm{q}}\right.$ arom $), 135.4\left(\mathrm{C}_{\mathrm{q}}\right.$ arom $), 135.8\left(\mathrm{C}_{\mathrm{q}}\right.$ arom $), 139.4\left(\mathrm{C}_{\mathrm{q}}\right.$ arom $), 140.0(\mathrm{CH}$ arom $), 140.3\left(\mathrm{C}_{\mathrm{q}}\right.$ arom $), 155.1\left(\mathrm{C}_{\mathrm{q}}\right.$ arom $), 161.1\left(\mathrm{C}_{\mathrm{q}}\right.$ arom), $177.0\left(\mathrm{~d}, J_{\mathrm{CRh}}=52 \mathrm{~Hz}, \mathrm{C}-2 \mathrm{NHC}\right)$
Complex 3c. Yellow-orange solid (63\%). Anal. Calcd for $\mathrm{C}_{34} \mathrm{H}_{39} \mathrm{BF}_{4} \mathrm{~N}_{3} \mathrm{O}_{2} \mathrm{Rh}$ (\%): C 57.40; $\mathrm{H}$ 5.53; N 5.91. Found: $\mathrm{C} 57.25 ; \mathrm{H}$ 5.53; N 5.85. MS (ESI, $\left.\mathrm{CH}_{2} \mathrm{Cl}_{2} / \mathrm{MeOH}\right): m / z 624\left(\left[M^{+}\right]^{+}, 100\right) .{ }^{1} \mathrm{H}$ NMR ( $\left.\mathrm{CD}_{2} \mathrm{Cl}_{2}, 400 \mathrm{MHz}\right): \delta 1.31(\mathrm{~m}, 1 \mathrm{H}, \mathrm{C} H \mathrm{H} \mathrm{COD}), 1.45(\mathrm{~m}, 2 \mathrm{H}$, $2 \mathrm{CHH}$ COD), $1.91(\mathrm{~m}, 4 \mathrm{H}, 4 \mathrm{CH} \mathrm{H} \mathrm{COD}), 1.92\left(\mathrm{~s}, 3 \mathrm{H}, \mathrm{CH}_{3}\right), 2.05(\mathrm{~s}$, $\left.3 \mathrm{H}, \mathrm{CH}_{3}\right), 2.35\left(\mathrm{~s}, 3 \mathrm{H}, \mathrm{CH}_{3}\right), 2.37(\mathrm{~m}, 1 \mathrm{H}, \mathrm{CH} \mathrm{H} \mathrm{COD}), 3.16(\mathrm{~m}, 1 \mathrm{H}$, $\mathrm{CH}=\mathrm{COD}), 3.34(\mathrm{~m}, 1 \mathrm{H}, \mathrm{CH}=\mathrm{COD}), 3.62\left(\mathrm{~s}, 3 \mathrm{H}, \mathrm{OCH}_{3}\right), 3.63(\mathrm{~s}$, $\left.3 \mathrm{H}, \mathrm{OCH}_{3}\right), 3.77(\mathrm{~m}, 1 \mathrm{H}, \mathrm{CH}=\mathrm{COD}), 4.82(\mathrm{~m}, 1 \mathrm{H}, \mathrm{CH}=\mathrm{COD}), 5.78$ $\left(\mathrm{d},{ }^{2} J_{\mathrm{HH}}=14.3 \mathrm{~Hz}, 1 \mathrm{H}\right.$, py-CHH$), 6.42\left(\mathrm{~d},{ }^{2} J_{\mathrm{HH}}=14.4 \mathrm{~Hz}, 1 \mathrm{H}\right.$, py$\mathrm{C} H \mathrm{H}), 6.58\left(\mathrm{~d},{ }^{3} J_{\mathrm{HH}}=8.3 \mathrm{~Hz}, 1 \mathrm{H}, \mathrm{H}\right.$ arom $), 6.75\left(\mathrm{~d},{ }^{3} J_{\mathrm{HH}}=8.7 \mathrm{~Hz}\right.$, $1 \mathrm{H}, \mathrm{H}$ arom), 6.76 (s, 1H, H arom), 6.96 (s, $1 \mathrm{H}, \mathrm{H}$ arom), 7.03 (s, 1H, $\mathrm{H}$ arom), $7.25\left(\mathrm{~d},{ }^{3} J_{\mathrm{HH}}=7.5 \mathrm{~Hz}, 1 \mathrm{H}, \mathrm{H}\right.$ arom $), 7.44\left(\mathrm{dd},{ }^{3} J_{\mathrm{HH}}=8.3\right.$ $\mathrm{Hz},{ }^{3} J_{\mathrm{HH}}=8.3 \mathrm{~Hz}, 1 \mathrm{H}, \mathrm{H}$ arom $), 7.64(\mathrm{~s}, 1 \mathrm{H}, \mathrm{H}$ arom $), 7.86\left(\mathrm{~d},{ }^{3} J_{\mathrm{HH}}=\right.$ $7.5 \mathrm{~Hz}, 1 \mathrm{H}, \mathrm{H}$ arom $), 7.91\left(\mathrm{dd},{ }^{3} J_{\mathrm{HH}}=7.5 \mathrm{~Hz},{ }^{3} J_{\mathrm{HH}}=7.5 \mathrm{~Hz}, 1 \mathrm{H}, \mathrm{H}\right.$ arom). ${ }^{13} \mathrm{C}\left\{{ }^{1} \mathrm{H}\right\}$ NMR $\left(\mathrm{CD}_{2} \mathrm{Cl}_{2}, 126 \mathrm{MHz}\right): \delta 18.0\left(\mathrm{CH}_{3}\right), 18.9\left(\mathrm{CH}_{3}\right)$, $21.1\left(\mathrm{CH}_{3}\right), 26.9\left(\mathrm{CH}_{2} \mathrm{COD}\right), 30.1\left(\mathrm{CH}_{2} \mathrm{COD}\right), 31.1\left(\mathrm{CH}_{2} \mathrm{COD}\right)$, $34.7\left(\mathrm{CH}_{2} \mathrm{COD}\right), 55.8\left(\mathrm{py}-\mathrm{CH}_{2}\right), 57.0\left(\mathrm{OCH}_{3}\right), 57.1\left(\mathrm{OCH}_{3}\right), 69.3(\mathrm{~d}$, $\left.J_{\mathrm{CRh}}=13 \mathrm{~Hz}, \mathrm{CH}=\mathrm{COD}\right), 73.7\left(\mathrm{~d}, J_{\mathrm{CRh}}=15 \mathrm{~Hz}, \mathrm{CH}=\mathrm{COD}\right), 96.8(\mathrm{~d}$, $\left.J_{\mathrm{CRh}}=7 \mathrm{~Hz}, \mathrm{CH}=\mathrm{COD}\right), 99.1\left(\mathrm{~d}, J_{\mathrm{CRh}}=7 \mathrm{~Hz}, \mathrm{CH}=\mathrm{COD}\right), 103.9(\mathrm{CH}$ arom), 105.0 (CH arom), 117.6 ( $\mathrm{C}_{\mathrm{q}}$ arom $), 122.2(\mathrm{CH}$ arom $), 124.2(2$ $\mathrm{CH}$ arom), 129.4 (CH arom), $129.5(\mathrm{CH}$ arom $), 129.6(\mathrm{CH}$ arom $)$, $132.0(\mathrm{CH}$ arom $), 135.0\left(\mathrm{C}_{\mathrm{q}}\right.$ arom $), 135.6\left(\mathrm{C}_{\mathrm{q}}\right.$ arom $), 135.8\left(\mathrm{C}_{\mathrm{q}}\right.$ arom $)$, 139.2 ( $\mathrm{CH}$ arom $), 139.7\left(\mathrm{C}_{\mathrm{q}}\right.$ arom $), 154.8\left(\mathrm{C}_{\mathrm{q}}\right.$ arom $), 158.6\left(\mathrm{C}_{\mathrm{q}}\right.$ arom $)$, $158.7\left(\mathrm{C}_{\mathrm{q}}\right.$ arom $), 159.4\left(\mathrm{C}_{\mathrm{q}}\right.$ arom $), 177.8\left(\mathrm{~d}, J_{\mathrm{CRh}}=52 \mathrm{~Hz}, \mathrm{C}-2 \mathrm{NHC}\right)$.

Procedure for the Generation of Complex 5. A solution of complex 3c $(0.025 \mathrm{~g}, 0.03 \mathrm{mmol})$ and $\mathrm{HSi}(\mathrm{OEt})_{3}(32 \mu \mathrm{L}, 0.17 \mathrm{mmol})$ in $\mathrm{CD}_{3} \mathrm{CN}(0.7 \mathrm{~mL})$ was heated at $60{ }^{\circ} \mathrm{C}$ for $16 \mathrm{~h}$. Volatiles were removed under vacuum, and the residue was dissolved in $\mathrm{CD}_{3} \mathrm{CN}$ and analyzed by NMR spectroscopy. Further attempts to purify complex $\mathbf{5}$ only produced significant decomposition. Signal assignations in the ${ }^{1} \mathrm{H}$ and ${ }^{13} \mathrm{C}\left\{{ }^{1} \mathrm{H}\right\}$ NMR spectra were made with the assistance of $2 \mathrm{D}$ NMR spectroscopy, including ${ }^{1} \mathrm{H},{ }^{1} \mathrm{H}-\mathrm{COSY},{ }^{1} \mathrm{H},{ }^{1} \mathrm{H}-\mathrm{NOESY}$, ${ }^{1} \mathrm{H},{ }^{13} \mathrm{C}\left\{{ }^{1} \mathrm{H}\right\}$-HMQC and ${ }^{1} \mathrm{H},{ }^{13} \mathrm{C}\left\{{ }^{1} \mathrm{H}\right\}$-HMBC experiments.

${ }^{1} \mathrm{H}$ NMR ( $\left.\mathrm{CD}_{3} \mathrm{CN}, 400 \mathrm{MHz}\right): \delta-17.46\left(\mathrm{~d},{ }^{1} J_{\mathrm{HRh}}=30.8 \mathrm{~Hz}, 1 \mathrm{H}\right.$, $\mathrm{RhH}), 0.99\left(\mathrm{t},{ }^{3} J_{\mathrm{HH}}=7.0 \mathrm{~Hz}, 9 \mathrm{H}, 3 \mathrm{SiOCH}_{2} \mathrm{CH}_{3}\right), 1.70\left(\mathrm{~s}, 3 \mathrm{H}, \mathrm{CH}_{3}\right)$, $2.25\left(\mathrm{~s}, 3 \mathrm{H}, \mathrm{CH}_{3}\right), 2.37\left(\mathrm{~s}, 3 \mathrm{H}, \mathrm{CH}_{3}\right), 3.60\left(\mathrm{q},{ }^{3} J_{\mathrm{HH}}=7.0 \mathrm{~Hz}, 6 \mathrm{H}, 3\right.$ $\left.\mathrm{SiOCH}_{2}\right), 3.84$ (overlapped, $\left.6 \mathrm{H}, 2 \mathrm{OCH}_{3}\right), 5.36\left(\mathrm{~d},{ }^{2} J_{\mathrm{HH}}=14.8 \mathrm{~Hz}\right.$, $1 \mathrm{H}$, py-CHH $), 6.00\left(\mathrm{~d},{ }^{2} J_{\mathrm{HH}}=14.8 \mathrm{~Hz}, 1 \mathrm{H}\right.$, py-CHH$), 6.80\left(\mathrm{br} \mathrm{d},{ }^{3} J_{\mathrm{HH}}\right.$ $=8.8 \mathrm{~Hz}, 2 \mathrm{H}, 2 \mathrm{H}$ arom $), 7.00\left(\mathrm{~d},{ }^{3} J_{\mathrm{HH}}=1.9 \mathrm{~Hz}, 1 \mathrm{H}, \mathrm{H}\right.$ arom $), 7.02(\mathrm{~s}$, $1 \mathrm{H}, \mathrm{H}$ arom), $7.11\left(\mathrm{~s}, 1 \mathrm{H}, \mathrm{H}\right.$ arom), $7.44\left(\mathrm{t},{ }^{3} J_{\mathrm{HH}}=8.8 \mathrm{~Hz}, 1 \mathrm{H}, \mathrm{H}\right.$ arom $), 7.46\left(\mathrm{~d},{ }^{3} J_{\mathrm{HH}}=1.9 \mathrm{~Hz}, 1 \mathrm{H}, \mathrm{H}\right.$ arom $), 7.50\left(\mathrm{~d},{ }^{3} J_{\mathrm{HH}}=7.8 \mathrm{~Hz}\right.$, $1 \mathrm{H}, \mathrm{H}$ arom), $7.70\left(\mathrm{dd},{ }^{3} J_{\mathrm{HH}}=7.7 \mathrm{~Hz},{ }^{4} J_{\mathrm{HH}}=1.2 \mathrm{~Hz}, 1 \mathrm{H}, \mathrm{H}\right.$ arom $)$, $8.03\left(\mathrm{dd},{ }^{3} J_{\mathrm{HH}}=7.7 \mathrm{~Hz},{ }^{3} J_{\mathrm{HH}}=7.7 \mathrm{~Hz}, 1 \mathrm{H}, \mathrm{H}\right.$ arom $) .{ }^{1} \mathrm{H},{ }^{29} \mathrm{Si}-\mathrm{HMQC}$ $\left(\mathrm{CD}_{3} \mathrm{CN}\right): \delta-34.3 \mathrm{ppm}\left(\mathrm{d}, J_{\mathrm{SiRh}}=62 \mathrm{~Hz}\right) .{ }^{13} \mathrm{C}\left\{{ }^{1} \mathrm{H}\right\} \mathrm{NMR}\left(\mathrm{CD}_{3} \mathrm{CN}\right.$, $101 \mathrm{MHz}): \delta 18.0\left(\mathrm{CH}_{3}\right), 18.3\left(3 \mathrm{SiOCH}_{2} \mathrm{CH}_{3}\right), 21.1\left(\mathrm{CH}_{3}\right), 56.4$ (py$\left.\mathrm{CH}_{2}\right), 58.6\left(3 \mathrm{SiOCH}_{2} \mathrm{CH}_{3}\right), 106.1(\mathrm{CH}$ arom $), 123.0(\mathrm{CH}$ arom), 124.0 (CH arom), 124.8 (CH arom), 129.7 (2 $\mathrm{CH}$ arom), $130.3(2 \mathrm{CH}$ arom $), 132.5(\mathrm{CH}$ arom $), 136.7\left(\mathrm{C}_{\mathrm{q}}\right.$ arom $), 137.2\left(\mathrm{C}_{\mathrm{q}}\right.$ arom $), 137.3\left(\mathrm{C}_{\mathrm{q}}\right.$ arom $), 139.9(\mathrm{CH}$ arom $), 140.2\left(\mathrm{C}_{\mathrm{q}}\right.$ arom $), 155.6\left(\mathrm{C}_{\mathrm{q}}\right.$ arom $), 157.5\left(\mathrm{C}_{\mathrm{q}}\right.$ arom), 159.4 ( $2 \mathrm{C}_{\mathrm{q}}$ arom), 173.6 (d, $\left.J_{\mathrm{CRh}}=54 \mathrm{~Hz}, \mathrm{C}-2 \mathrm{NHC}\right)$. Signals corresponding to one $\mathrm{CH}_{3}$ from the mesityl fragment, the two $\mathrm{OCH}_{3}$, and one quaternary aromatic carbon could not be unambiguously assigned. MS (ESI, MeCN): $m / z 680\left(\left[M-2 \mathrm{MeCN}_{-} \mathrm{BF}_{4}\right]^{+}, 100\right)$. Fragmentation of ion $m / z=680: \mathrm{m} / z 516\left(\left[M-2 \mathrm{MeCN}^{-} \mathrm{BF}_{4-}\right.\right.$ $\left.\left.\mathrm{HSi}(\mathrm{OEt})_{3}\right]^{+}, 100\right)$

Representative Procedure for Catalytic Hydrosilylation Reactions. In a glovebox, a NMR tube was charged with a solution of complex 3c $(0.4 \mathrm{mg}, 0.56 \mu \mathrm{mol})$, phenylacetylene $(31 \mu \mathrm{L}, 0.28 \mathrm{mmol})$ and tri- $n$-propylsilane $(57 \mu \mathrm{L}, 0.31 \mathrm{mmol})$ in $\mathrm{CD}_{2} \mathrm{Cl}_{2}(0.5 \mathrm{~mL})$. The reaction was heated to $60{ }^{\circ} \mathrm{C}$ (oil bath) for $4 \mathrm{~h}$. Conversion was determined by ${ }^{1} \mathrm{H}$ NMR spectroscopy or GC-MS using mesitylene as internal standard, while the $E / \alpha$ ratio was obtained by ${ }^{1} \mathrm{H}$ NMR spectroscopy.

\section{ASSOCIATED CONTENT}

Supporting Information 
The Supporting Information is available free of charge on the ACS Publications website.

Synthetic procedures and analytical data for derivatives 1, 2 and 4; NMR spectra; $\mathrm{VT}^{-1} \mathrm{H}$ NMR spectra of 3; analytical data of hydrosilylation products; competition experiments; X-ray diffraction details (PDF)

Crystallographic data files (CIF)

\section{AUTHOR INFORMATION}

\section{Corresponding Authors}

*E-mail for V.S.: salazar@uaeh.edu.mx

E-mail for A.S.: andres.suarez@iiq.csic.es

\section{Notes}

The authors declare no competing financial interest.

\section{ACKNOWLEDGMENT}

Financial support (FEDER contribution) from the Spanish MINECO (CTQ2013-45011-P, CTQ2016-80814-R and CTQ2016-81797-REDC) is gratefully acknowledged. P.L. thanks the Spanish MINECO for a Juan de la Cierva contract. Prof. Ernesto Carmona (IIQ) is thanked for a generous loan of catalyst for silane deuteration.

\section{REFERENCES}

(1) (a) Langkopf, E.; Schinzer, D. Chem. Rev. 1995, 95, 13751408. (b) Fleming, I.; Dunogues, J.; Smithers, R. Org. React. 1989, 37, 57-575. (c) Fleming, I.; Barbero, A.; Walter, D. Chem. Rev. 1997, 97, 2063-2192. (d) Denmark, S. E.; Ober, M. H. Aldrichimica Acta 2003, 36, 75-85. (e) Denmark, S. E.; Sweis, R. F. Acc. Chem. Res. 2002, 35, 835-846. (f) Blumenkopf, T. A.; Overman, L. E. Chem. Rev. 1986, 86, 857-873. (g) Jones, G. R.; Landais, Y. Tetrahedron 1996, 52, 7599-7662. (h) Hiyama, T.; Shirakawa, E. Top. Curr. Chem. 2002, 219, 61-85. (i) Komiyama, T.; Minami, Y.; Hiyama, T. ACS Catal. 2017, 7, 631-651.

(2) (a) Marciniec, B.; Maciejewski, H.; Pietraszuk, C.; Pawluc, P. Hydrosilylation of Alkynes and their derivatives. In Hydrosilylation. A Comprehensive Review of Recent Advances; Marciniec, B., Ed.; Advances in Silicon Science; Springer; 2009. (b) Roy, A. K. Adv. Organomet. Chem. 2008, 55, 1-59. (c) Lim, D. S. W.; Anderson, E. A. Synthesis 2012, 44, 983-1010. (d) Trost, B. M.; Ball, Z. T. Synthesis 2005, 6, 853-887.

(3) For selected examples: (a) Doyle, M. P.; High, K. G.; Nesloney, C. L.; Clayton, T. W.; Lin, J. Organometallics 1991, 10, 1225-1226. (b) Lewis, L. N.; Sy, K. G.; Bryant, G. L.; Donahue, P. E. Organometallics 1991, 10, 3750-3759. (c) Murphy, J. P.; Spencer, J. L.; Procter, G. Tetrahedron Lett. 1990, 31, 1051-1054. (d) Takahashi, K.; Minami, T.; Ohara, Y.; Hiyama, T. Tetrahedron Lett. 1993, 34, 8263-8266. (e) Denmark, S. E.; Wang, Z. Org. Lett. 2001, 3, 10731076. (f) Itami, K.; Mitsudo, K.; Nishino, A.; Yoshida, J. J. Org. Chem. 2002, 67, 2645-2652. (g) Blug, M.; Le Goff, X.-F.; Mézailles, N.; Le Floch, P. Organometallics 2009, 28, 2360-2362. (h) Wu, W.; Li, C-J. Chem. Commun. 2003, 1668-1669. (i) Aneetha, H.; Wu, W.; Verkade, J. G. Organometallics 2005, 24, 2590-2596. (j) De Bo, G.; Berthon-Gelloz, G.; Tinant, B.; Markó, I. E. Organometallics 2006, 25, 1881-1890. (k) Berthon-Gelloz, G.; Schumers, J.-M.; De Bo, G.; Markó, I. E. J. Org. Chem. 2008, 73, 4190-4197. (1) Silbestri, G. F.; Flores, J. C.; de Jesús, E. Organometallics 2012, 31, 3355-3360. (m) Ortega-Moreno, L.; Peloso, R.; Maya, C.; Suárez, A.; Carmona, E. Chem. Commun. 2015, 51, 17008-17011. (n) Dierick, S.; Vercruysse, E.; Berthon-Gelloz, G.; Markó, I. E. Chem. Eur. J. 2015, 21, 1707317078.

(4) For examples of selective $\beta$-(Z)-vinylsilane formation with $\mathrm{Ru}$ catalysts: (a) Esteruelas, M. A.; Herrero, J.; Oro, L. A. Organometallics 1993, 12, 2377-2379. (b) Na, Y.; Chang, S. Org.
Lett. 2000, 2, 1887-1889. (c) Katayama, H.; Taniguchi, K.; Kobayashi, M.; Sagawa, T.; Minami, T.; Ozawa, F. J. Organomet. Chem. 2002, 645, 192-200. (d) Nagao, M.; Asano, K.; Umeda, K.; Katayama, H.; Ozawa, F. J. Org. Chem. 2005, 70, 10511-10514. (e) Maifeld, S. V.; Tran, M. N.; Lee, D. Tetrahedron Lett. 2005, 46, 105108. (f) Gao, R.; Pahls, D. R.; Cundari, T. R.; Yi, C. S. Organometallics 2014, 33, 6937-6944. (g) Conifer, C.; Gunanathan, C.; Rinesch, T.; Hölscher, M.; Leitner, W. Eur. J. Inorg. Chem. 2015, 333-339.

(5) For $\alpha$-selective Ru catalysts: (a) Trost, B. M.; Ball, Z. T. J. Am. Chem. Soc. 2001, 123, 12726-12727. (b) Kawanami, Y.; Sonoda, Y.; Mori, T.; Yamamoto, K. Org. Lett. 2002, 4, 2825-2827. (c) Trost, B. M.; Ball, Z. T. J. Am. Chem. Soc. 2005, 127, 17644-17655.

(6) For selected examples: (a) Tanke, R. S.; Crabtree, R. H. J. Am. Chem. Soc. 1990, 112, 7984-7989. (b) Jun, C-H.; Crabtree, R. H. J. Organomet. Chem. 1993, 447, 177-187. (c) Esteruelas, M. A.; Oliván, M.; Oro, L. A. Organometallics 1996, 15, 814-822. (d) Vicent, C.; Viciano, M.; Mas-Marzá, E.; Sanaú, M.; Peris, E. Organometallics 2006, 25, 3713-3720. (e) Miyake, Y.; Isomura, E.; Iyoda, M. Chem. Lett. 2006, 35, 836-837. (f) Sridevi, V. S.; Fan, W. Y.; Leong, W. K. Organometallics 2007, 26, 1157-1160. (g) Iglesias, M.; Sanz Miguel, P. J.; Polo, V.; Fernández-Álvarez, F. J.; Pérez-Torrente, J. J.; Oro, L. A. Chem. Eur. J. 2013, 19, 17559-17566. (h) Pérez-Torrente, J. J.; Nguyen, D. H.; Jiménez, M. V.; Modrego, F. J.; Puerta-Oteo, R.; Gómez-Bautista, D.; Iglesias, M.; Oro, L. A. Organometallics 2016, $35,2410-2422$.

(7) (a) Takeuchi, R.; Tanouchi, N. J. Chem. Soc., Chem. Commun. 1993, 1319-1320. (b) Takeuchi, R.; Tanouchi, N. J. Chem. Soc., Perkin Trans. 1 1994, 2909-2913.

(8) Faller, J. W.; D'Alliessi, D. G. Organometallics 2002, 21, 1743-1746, and references therein.

(9) Sato, A.; Kinoshita, H.; Shinokubo, H.; Oshima, K. Org. Lett. 2004, 6, 2217-2220.

(10) (a) Takeuchi, R.; Nitta, S.; Watanabe, D. J. Chem. Soc., Chem. Commun. 1994, 1777-1778. (b) Takeuchi, R.; Nitta, S.; Watanabe, D. J. Org. Chem. 1995, 60, 3045-3051. (c) Takeuchi, R.; Ebata, I. Organometallics 1997, 16, 3707-3710.

(11) Ojima, I.; Clos, N.; Donovan, R. J.; Ingallina, P. Organometallics 1990, 9, 3127-3133; and references therein.

(12) (a) Mori, A.; Takahisa, E.; Kajiro, H.; Nishihara, K.; Hiyama, T. Chem. Lett. 1998, 443-444. (b) Mori, A.; Takahisa, E.; Yamamura, Y.; Kato, T.; Mudalige, A. P.; Kajiro, H.; Hirabayashi, K.; Nishihara Y.; Hiyama, T. Organometallics 2004, 23, 1755-1765.

(13) (a) Andavan, G. T. S.; Bauer, E. B.; Letko, C. S.; Hollis, T. K.; Tham, F. S. J. Organomet. Chem. 2005, 690, 5938-5947. (b) Rivera, G.; Elizalde, O.; Roa, G.; Montiel, I.; Bernès, S. J. Organomet. Chem. 2012, 699, 82-86. (c) Huckaba, A. J.; Hollis, T. K.; Howell, T. O.; Valle, H. U.; Wu, Y. Organometallics 2013, 32, 63-69.

(14) (a) Hill, J. E.; Nile, T. A. J. Organomet. Chem. 1977, 137, 293-300. (b) Lappert, M. F.; Maskell, R. K. J. Organomet. Chem. 1984, 264, 217-228. (c) Zeng, J. Y.; Hsieh, M.-H.; Lee, H. M. J. Organomet. Chem. 2005, 690, 5662-5671. (d) Poyatos, M.; MasMarzá, E.; Mata, J. A.; Sanaú, M.; Peris, E. Eur. J. Inorg. Chem. 2003, 1215-1221. (e) Mas-Marzá, E.; Poyatos, M.; Sanaú, M.; Peris, E. Inorg. Chem. 2004, 43, 2213-2219. (f) Poyatos, M.; MaisseFrançois, A.; Bellemin-Laponnaz, S.; Gade, L. H. Organometallics 2006, 25, 2634-2641. (g) Viciano, M.; Mas-Marzá, E.; Sanaú, M.; Peris, E. Organometallics 2006, 25, 3063-3069. (h) Iglesias, M.; Aliaga-Lavrijsen, M.; Sanz Miguel, P. J.; Fernández-Álvarez, F. J.; Pérez-Torrente, J. J.; Oro, L. A. Adv. Synth. Catal. 2015, 357, 350354.

(15) Mas-Marzá, E.; Sanaú, M.; Peris, E. Inorg. Chem. 2005, 44, 9961-9967.

(16) (a) Jiménez, M. V.; Pérez-Torrente, J. J.; Bartolomé, M. I.; Gierz, V.; Lahoz, F. J.; Oro, L. A. Organometallics 2008, 27, 224234. (b) Busetto, L.; Cassani, M. C.; Femoni, C.; Mancinelli, M.; Mazzanti, A.; Mazzoni, R.; Solinas, G. Organometallics 2011, 30, 5258-5272. (c) Cassani, M. C.; Brucka, M. A.; Femoni, C.; Mancinelli, M.; Mazzanti, A.; Mazzoni, R.; Solinas, G. New J. Chem. 2014, 38, 1768-1779. (d) Mancano, G.; Page, M. J.; Bhadbhade, M.; 
Messerle, B. A. Inorg. Chem. 2014, 53, 10159-10170. (e) Diachenko, V.; Page, M. J.; Gatus, M. R. D.; Bhadbhade, M.; Messerle, B. Organometallics 2015, 34, 4543-4552.

(17) (a) Ishikawa, Y.; Yamamoto, Y.; Asao, N. Catal. Sci. Technol. 2013, 3, 2902-2905. (b) Caporusso, A. M.; Aronica, L. A.; Schiavi, E.; Martra, G.; Vitulli, G.; Salvadori, P. J. Organomet. Chem. 2005, 690, 1063-1066. (c) Psyllaki, A.; Lykakis. I. N.; Stratakis, M. Tetrahedron 2012, 68, 8724-8731.

(18) (a) Mo, Z.; Xiao, J.; Gao, Y.; Deng, L. J. Am. Chem. Soc. 2014, 136, 17414-17417. (b) Guo, J.; Lu, Z. Angew. Chem., Int. Ed. 2016, $55,10835-10838$.

97.

(20) Goldberg, Y.; Alper, H. J. Chem. Soc., Chem. Commun. 1994, 1209-1210

(21) (a) Hopkinson, M. N.; Richter, C.; Schedler, M.; Glorius, F. Nature 2014, 510, 485-496. (b) Díez-González, S.; Marion, N.; Nolan, S. P. Chem. Rev. 2009, 109, 3612-3676.

(22) (a) Wang, C-Y.; Liu, Y-H.; Peng, S-M.; Liu, S-T. J. Organomet. Chem. 2006, 691, 4012-4020. (b) Warsink, S.; van Aubel, C. M. S.; Weigand, J. J.; Liu, S-T.; Elsevier, C. J. Eur. J. Inorg. Chem. 2010, 5556-5562. (c) Cao, C.; Sun, R.; Chen, Q.; Lv, L.; Shi, Y.; Pang, G. Transition Met. Chem. 2013, 38, 351-358.

(23) (a) Garrison, J. C.; Youngs, W. J. Chem. Rev. 2005, 105, 3978-4008. (b) Lin, I. J. B.; Vasam, C. S. Coord. Chem. Rev. 2007, $251,642-670$

(24) Yu, X.-Y.; Patrick, B. O.; James, B. R. Organometallics 2006, 25, 2359-2363; and references therein.

(25) Braunstein, P.; Naud, F. Angew. Chem., Int. Ed. 2001, 40, 680-699; and references therein.

(26) (a) Gründemann, S.; Albrecht, M.; Loch, J. A.; Faller, J. W.; Crabtree, R. H. Organometallics 2001, 20, 5485-5488. (b) Miecznikowski, J. R.; Gründemann, S.; Albrecht, M.; Mégret, C.; Clot, E.; Faller, J. W.; Eisenstein, O.; Crabtree, R. H. Dalton Trans. 2003, 831-838. (c) Hernández-Juárez, M.; López-Serrano, J.; Lara, P.; Morales-Cerón, J. P.; Vaquero, M.; Álvarez, E.; Salazar, V.; Suárez, A. Chem. Eur. J. 2015, 21, 7540-7555.

(27) Wang, C-Y.; Fu, C-F.; Liu, Y-H.; Peng, S-M.; Liu, S-T. Inorg. Chem. 2007, 46, 5779-5786.

(28) For comparison with other catalytic systems, the reaction of phenylacetylene with $\mathrm{Et}_{3} \mathrm{SiH}$ was also carried out. Identical catalytic activity and selectivity to the reaction with ${ }^{n} \mathrm{Pr}_{3} \mathrm{SiH}$ were observed.

(29) For selected examples of the influence of the steric hindrance of hemilabile ligand fragments on selectivity: (a) Khlebnikov, V.; Meduri, A.; Mueller-Bunz, H.; Montini, T.; Fornasiero, P.; Zangrando, E.; Milani, B.; Albrecht, M. Organometallics 2012, 31, 976-986. (b) Warsink, S.; Chang, I-H.; Weigand, J. J.; Hauwert, P.; Chen, J-T.; Elsevier, C. J. Organometallics 2010, 29, 4555-4561. (c) Flapper, J.; van Leeuwen, P. W. N. M.; Elsevier, C. J.; Kamer, P. C. J. Organometallics 2009, 28, 3264-3271.

(30) Lukevics, E.; Dzintara, M. J. Organomet. Chem. 1985, 295, 265-315.

(31) Chalk, A. J.; Harrod, J. F. J. Am. Chem. Soc. 1965, 87, 16-21.

(32) (a) Tabata, M.; Yang, W.; Yokota, K. Polym. J. 1990, 22, 1105-1107. (b) Amer, I.; Schumann, H.; Ravindar, V.; Baidossi, W.; Goren, N.; Blum, J. J. Mol. Catal. 1993, 85, 163-171. (c) Kishimoto, Y.; Eckerle, P.; Miyatake, T.; Ikariya, T.; Noyori, R. J. Am. Chem. Soc. 1994, 116, 12131-12132. (d) Kishimoto, Y.; Miyatake, T.; Ikariya, T.; Noyori, R. Macromolecules 1996, 29, 5054-5055.

(33) (a) Gómez-Gallego, M.: Sierra, M. A. Chem. Rev. 2011, 111, 4857-4963. (b) Simmons, E. M.; Hartwig, J. F. Angew. Chem. Int. Ed. 2012, 51, 3066-3072. 

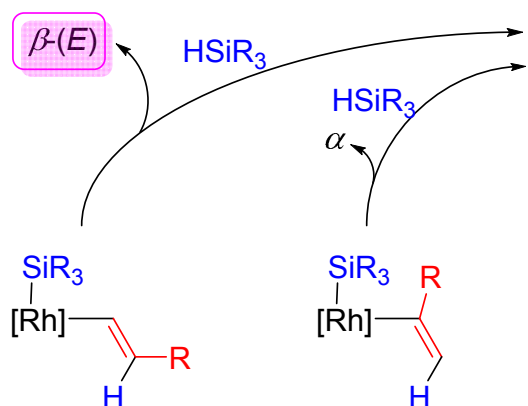

$\mathrm{C}^{H}(E)$

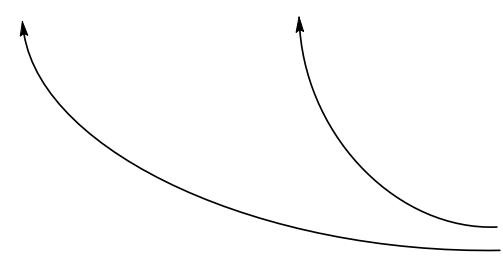

alkyne insertion into the $\underline{R h-H}$ bond
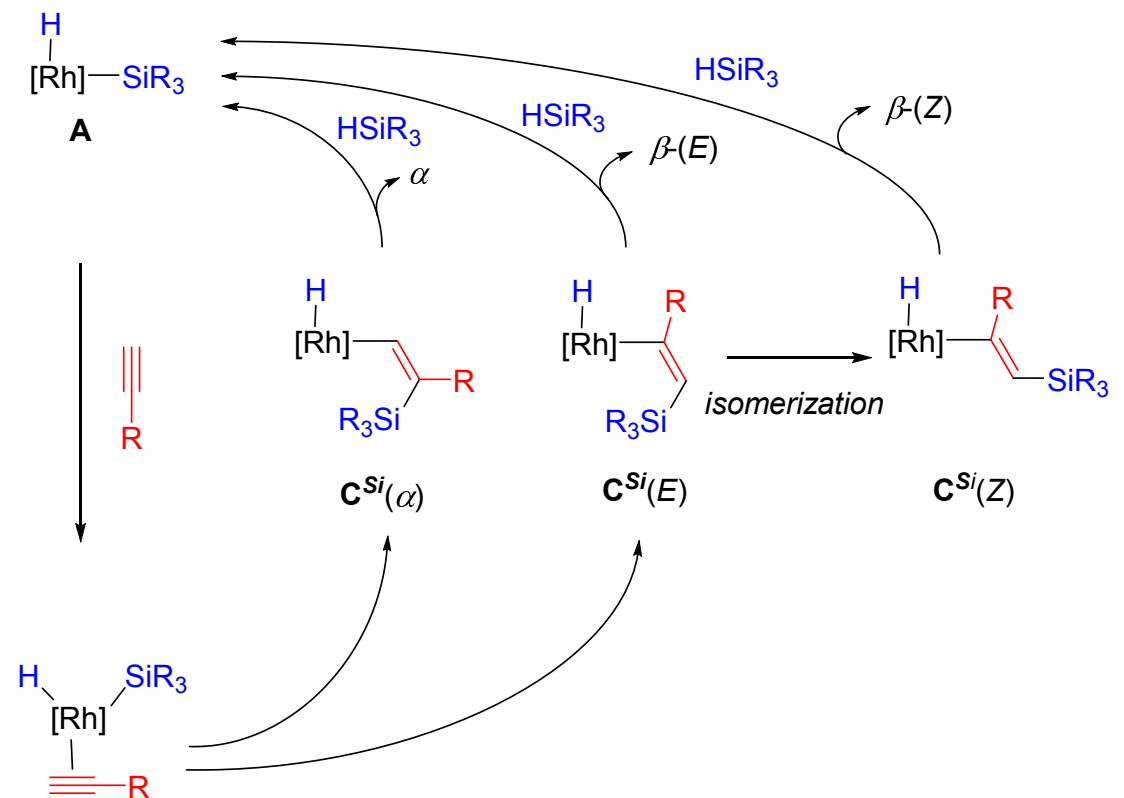

B

alkyne insertion into the $\underline{R h-S i} \underline{\text { bond }}$

Figure 3. Proposed pathways for the standard and modified Chalk-Harrod mechanisms for alkyne hydrosilylation catalyzed by 3. 


$$
\| \mathrm{R}_{\mathrm{R}}+\mathrm{R}_{3} \mathrm{SiH} \stackrel{[\mathrm{Rh}]}{\longrightarrow} \underset{\mathrm{R}}{\rightleftharpoons} \stackrel{\mathrm{SiR}_{3} \quad \mathrm{R}_{3} \mathrm{Si}}{{ }_{\mathrm{R}} \Longleftarrow \alpha}
$$

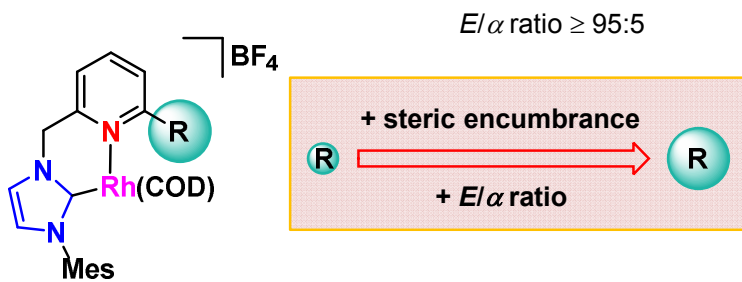

